\title{
The geochemistry of natural wetlands in former uranium milling sites (Eastern Germany) and its implications for
}

\author{
uranium retention
}

Schöner, A., Noubactep, C., Büchel, G. \& Sauter, M.

\begin{abstract}
Discharge from former uranium mining and milling areas is world wide a source of elevated uranium contents in wetlands. The efficiency of organic rich wetland environments for entrapment and accumulation of uranium was assessed in this work using hydrogeochemical field studies of natural small-sized wetlands in Thuringia and Saxony, Eastern Germany. The objective was to estimate, if artificial wetlands can be used in a similar way: as a sustainable 'passive' treatment methodology. World wide, as an experiment a first dozen of such systems is implemented for uranium bearing mine waters, primarily aiming at uranium reduction and precipitation.

Pore water and solid phase samples were collected from the upper decimetres of substrate profiles in minerotrophic volunteer wetlands and natural fen-type wetlands which facilitate uranium accumulation. Elemental analyses, correlation techniques and sequential chemical extraction were applied to evaluate retention mechanisms (e.g., reduction, mineral sorption). No dominant process was pronounced, but the bulk of uranium is retained in moderately labile forms, predominantly as operationally defined organically bound or acid soluble ('specifically adsorbed') phases. Macrophyte intracellular uranium accumulation ('phytoaccumulation') is not responsible for the high uranium concentrations in the wetland substrates. Although there is no evidence for stable U(IV) mineralisation via 'reductive precipitation', high accumulation efficiency of the wetlands is obvious, resulting from processes regarded as more labile. According to the findings, the construction target of wetlands has to be reconsidered, not primarily aiming at uranium reduction.
\end{abstract}


Keywords: Wetland, uranium, trace metal, treatment wetland, uranium reduction, sequential extraction, hydrogeochemistry, peat.

\section{INTRODUCTION}

\subsection{Uranium in the environment}

Natural uranium consists of radioactive isotopes which are predominantly alpha-emitting. Additionally, uranium as heavy metal is chemically toxic, therefore posing a health risk when incorporated, especially in aqueous species. In the aquifer, uranium represents a hazard to the environment and human health, at least if present in elevated concentrations. In a provisional guideline, the World Health Organization proposes a threshold value of $15 \mu \mathrm{g}$ of uranium per litre for drinking-water quality (WHO, 2005). In order to be able to characterise the hazard potential in a natural environment, it is essential to know the main uranium species present (dissolved, suspended, or immobilised in the sediment).

In natural aquatic systems uranium is stable as $\mathrm{U}(\mathrm{VI})$ or $\mathrm{U}(\mathrm{IV})$, depending on redox conditions, and emerges in dissolved, particulate, organic and inorganic species. Oxidised hexavalent $\mathrm{U}(\mathrm{VI})$ species are highly soluble and transported as uranyl ion $\left(\mathrm{UO}_{2}{ }^{2+}\right)$, usually complexed with major anions. Therefore, uranium is an element ubiquitous particularly in oxygenated surface water. The global average seawater concentration of $U$ is about $0.3 \mu \mathrm{g} / \mathrm{L}$ (Li, 1982), which is similarly suggested for river water (Palmer and Edmond, 1993). In Germany, random groundwater and drinking water samples revealed U concentrations between 1 and more than $100 \mu \mathrm{g} / \mathrm{L}$ (BfR, 2007; Höller et al., 2005; Merkel, 2006), deducible primarily from geogenic input (Baier, 2004; Schönwiese, 2007). This points to a necessity of expanded water purification measures not only in regions influenced from former uranium 
mining like in parts of Saxony and Thuringia, Eastern Germany, with special focus on costeffective methods.

\subsection{Natural wetlands accumulating uranium}

Natural wetlands, i.e., habitats frequently water saturated and highly productive, notoriously act as potential sinks for hazardous trace elements (Schell et al., 1989; Owen et al., 1992; Cole, 1998). Hence they enable the enrichment or even elimination of toxic elements and metals from discharges either anthropogenic contaminated or geogenic heavily loaded. In some cases they emerge as potentially recoverable deposits with elevated contaminant concentrations (Owen and Otton, 1995).

Since the beginning of the atomic age, a number of large-area wetlands were investigated in the vicinity of uranium-rich source rocks in Russia and Western USA. Many wetlands exposed certain uranium enrichment as compared to geogenic concentrations. Mean uranium concentrations of the upper crust are about $2 \mathrm{mg} / \mathrm{kg}$ (e.g. Ballenweg, 2005). As a rule, U concentrations in wetland substrates are categorised as highly enriched if ranging from 100 to $1000 \mathrm{mg} / \mathrm{kg} \mathrm{DM}$, and very highly enriched if exceeding $1000 \mathrm{mg} / \mathrm{kg}$ (Owen et al., 1992). By comparing inflow $(\mathrm{mg} / \mathrm{L})$ and substrate $(\mathrm{mg} / \mathrm{kg})$ uranium concentrations, high enrichment factors were estimated for the wetland substrates, ranging from 500 times up to 2 million times (Kochenov et al., 1965; Lopatkina, 1967; Idiz et al., 1986; Owen et al., 1992). Even in Germany with limited area, natural wetlands exhibit certain uranium concentrations (Landgraf et al., 2002; Seidel, 2002; Schöner, 2006). Our pilot survey has shown extremely high enrichment with factors up to 22000 times (Schöner, 2006). These occurrences are linked to disturbed landscapes like former uranium mining areas, and in this particular case mostly they are recent formations. Regarding long-term efficacy, the development of surficial uranium deposits is not necessarily a matter of geological time-scales, but also from retention capacity. 


\subsection{Implications of uranium accumulation}

Up to now, a limited number of studies investigated the processes of uranium extraction from

the aquatic solution in wetland substrates (e.g., Akber et al., 1992; Payne et al., 1998), moreover with critical gaps in field-based research. On the other hand, for water purification purposes first attempts to precipitate uranium in constructed wetland-like systems were started, e.g., in Australia (Shinners, 1996), Slovenia (Veselic et al., 2001), Bulgaria (Groudev et al., 1999), and Germany (Gerth et al., 2000). Worldwide, a dozen of uranium treatment wetlands are proved, but with ambiguous efficiency. The mechanisms of uranium entrapment and accumulation are yet unexplored, as well as the long-term stability of uranium species occurring in wetland substrates.

Uranium mobility is controlled in large part by the composition of the groundwater, which contains natural and contaminant $\mathrm{U}(\mathrm{VI})$-complexing ligands such as carbonate, phosphate and sulphate ions and organic chelators (e.g., Dybek, 1962). Outstanding thereby are aqueous uranyl carbonate complexes (Langmuir, 1978), which additionally hold inhibitory effects especially for bioreduction of uranium (e.g., Zhou and Gu, 2005). Uranium (IV) minerals are known to be barely soluble under reducing conditions. Hence 'reductive precipitation' of uranium minerals is regarded a major and sustainable mechanism. It is frequently aimed at in constructed wetland-type systems (Hallett et al., 1997; Groudev et al., 2000; Veselic et al., 2001), in particular microbial mediated reduction of uranyl ions as described by Lovley et al. (1991). In extreme contrast, it was an open question whether this pathway is significant in natural wetlands, and if so, whether this can be applied as a model for designing artificial wetlands.

Adsorption by plants or inorganic substrates is also believed to be important (e.g., Duff et al., 1999). Basically, initial fixation may be due to adsorption, rather than due to reductive precipitation (Zielinski et al., 1987). Regarding uranium fixation on solids, most effective 
sorption of the uranyl cation occurs at slightly acidic to neutral $\mathrm{pH}$ conditions (Langmuir, 1978; Duff and Amrhein, 1996). Fe-oxides, such as goethite $(\alpha-\mathrm{FeOOH})$ and ferrihydrite $\left(\mathrm{Fe}_{2} \mathrm{O}_{3} \bullet \mathrm{xH}_{2} \mathrm{O}\right)$, are frequently implicated as being among the most important inorganic adsorbent phases for $\mathrm{U}(\mathrm{VI})$, due to their ubiquity in waters and sediments especially in mining areas, and their high surface areas (Ames et al., 1983; Hsi and Langmuir, 1985; Bruno et al., 1995; Gabriel et al., 1998). Furthermore, organic carbon is a major uranium binding partner in soils and sediments (Moore, 1954; Swanson and Vine, 1958; Zielinski et al., 1987; Gruau et al., 2000), especially in wetlands. Although uranium sorption on wetland sediments may be very strong, it is normally not an irreversible process. Unless accompanied by coprecipitation or occlusion (Duff and Amrhein, 1996), re-mobilisation of uranium must be expected consequently.

\subsection{Aim and scope of the study}

This study aimed at elucidating mechanisms for uranium fixation in natural wetlands by (1) characterising hydrogeological parameters in natural wetlands in Eastern Germany, (2) collecting sediment samples at relevant sites and characterising them with hydrogeochemical methods, and (3) discussing the results on the basis of findings from laboratory investigations and literature data. The results may help to improve current treatment system design, and therefore the efficacy of artificial wetlands for uranium remediation.

In more detail, a pilot survey of wetlands aimed at finding relevant sites with evidence for secondary uranium accumulation derived from surficial tributary. Of three relevant wetlands, comprehensive field and laboratory studies were assessed on samples from 22 stratified substrate horizons. Here, the elemental composition of the aquatic phase and solid phase (screening of substrates and macrophytes) is presented, as well as the statistical evaluation using correlation techniques. As many competing reactions can occur between U(VI), surfaces, and ligands, promoting both fixation and re-mobilisation reactions, the relationships 
from $U$ concentration to other dissolved elements or aquatic parameters were estimated in order to outline geochemical processes which control the mobilisation and dissemination of uranium in the wetland environment. The association of uranium with different soil fractions was characterised by sequential chemical extraction, especially to estimate the weakness of uranium fixation.

\section{AREA DESCRIPTION}

\subsection{Wetland locations for pilot survey}

In the study area in eastern Germany, a state owned company, last named Wismut GmbH, was in charge of uranium mining and milling (1946 to 1991), and since 1989 of remediation. The mined uranium ore at the Ronneburg mine district was in the range of 200 to $300 \mathrm{mg} / \mathrm{kg}$ on average (Schuster, 1995). Natural wetlands (Figure 1) were surveyed in the vicinity of the former operation sites Ronneburg, Seelingstädt (federal state of Thuringia) and Crossen (federal state of Saxony), which are located some $60 \mathrm{~km}$ south of Leipzig between the cities of Gera and Zwickau. As affected by mine-related activities, the availability of sufficient water supply provides the natural or deliberate establishment of small wetlands ('volunteer wetlands'). Most of them are fed by waste-rock runoff water and subsequently developed in creek beds, natural stream channels or at the bottom of heaps or dams and colonised by wetland vegetation. Secondarily, also natural fen-type wetlands were sampled, anthropogenic influenced only recently through uranium processing.

A pilot survey of approximately 20 small-sized wetlands examined the hydrogeological setting, the organic carbon (OC) concentrations and the uranium concentrations (inflow and outflow, wetland substrates, background sediments). 


\subsection{Area description for detailed investigations}

Three wetlands could be successfully applied for advanced investigations of redox conditions and bonding forms. Located in the vicinity of tailing impoundments (IAA), hereinafter these are labelled wetland Helmsdorf (WLHe), wetland Culmitzsch (WLCu), and wetland Zinnborn (WLZ), respectively (compare Figure 1). Resuming uranium concentrations, background values, enrichment and exposure conditions, these three wetlands indicate uranium accumulations resulting probably from biochemical cycling.

A summary of the general characteristics for the wetlands is shown in Table 1, including ranges of $\mathrm{OC}$ and $\mathrm{U}$ concentrations. Two of the three surveyed wetland areas (Helmsdorf and Zinnborn) are situated on Rotliegend sediments (Permian) without uranium content in the bedrock. Here, the only source for uranium input is the former milling activity. In contrast, wetland Culmitzsch developed on phyllitic shale (Ordovician), which was mined at face with medium to high uranium concentrations of some 10 to $100 \mathrm{mg} / \mathrm{kg}$.

In Helmsdorf and Culmitzsch the unconsolidated wetland substrates consist of inorganic detritus and degraded plant material with a depth of up to $1 \mathrm{~m}$. The substrate layers of Helmsdorf are water saturated almost throughout the whole year, whereas in Culmitzsch they are covered by some decimetres of free water table. Wetland Helmsdorf and Culmitzsch are located adjacent to constructed earth-fill dams. The dams stabilise U-extraction waste in the tailing impoundments, i.e., highly contaminated, carboniferous, fine grained material. Therefore, these wetlands have ponded as recently as ore milling was started, 45 years ago at most. Diffuse seepage from the dams has washed fine-grained sediments into the ponds. In the Helmsdorf area, tailings with 49 to $270 \mathrm{mg} / \mathrm{kg} \mathrm{U}$ were deposited, the tailings water containing mean $7 \mathrm{mg} / \mathrm{L}$ U (Wismut $\mathrm{GmbH}$, 1999). Of IAA Culmitzsch tailings, U concentrations are reported with mean $82 \mathrm{mg} / \mathrm{kg}$ in the solid and $7 \mathrm{mg} / \mathrm{L}$ in water. The earth- 
fill dam adjacent to the wetland was built of spoil heap material containing up to $17 \mathrm{mg} / \mathrm{kg} \mathrm{U}$ (ibd.).

The third selected wetland, Zinnborn, is one out of many small ponds in a pre-existing boggy forest (fen). This wetland area contains up to $50 \mathrm{~cm}$ of peat with an impermanent water freeboard. Temporarily, substrate oxygenation is expected. The area developed approximately $500 \mathrm{~m}$ downstream IAA Helmsdorf and further tailing impoundments (IAA Dänkritz). Only after deposition of the tailings, uranium loaded seepage has been feeding diffuse springs which now originate in WLZ.

Combining results from inorganic sulphur speciation and sequential extraction (Schöner, 2006), allows for a detailed redox characterisation of the wetland environments according to Berner (1981). Mainly from associations of monosulphide sulphur to reduced Mn and Fe, for Zinnborn a primary oxic environment is deducible. Helmsdorf and Culmitzsch exhibit sulphidic environmental conditions with elevated pyritic sulphur and Mn.

\section{MATERIAL AND METHODS}

\subsection{Sampling and sample preparation}

Of the wetland ponds, free water, respectively supernatant water, as well as aboveground inflow and outflow was collected in PE vessels. Aliquots were filtered through $0.45 \mu \mathrm{m}$ membrane filters (cellulose acetate), some stabilised with concentrated $\mathrm{HNO}_{3}$ (suprapure). The unconsolidated, waterlogged, mainly organic-rich wetland substrates were intersected vertical. Following a stratification (22 strata, compare Table 2) which was based on a visual distinction of the material, i.e., organic matter content, substrate samples were consecutively excavated and stored under argon atmosphere. In the laboratory, pore water was extracted by 
centrifugating and $\mathrm{pH}$ and conductivity were measured. For hydrochemical analyses, they were filtered and acidified.

Additional wetland substrate samples in distances of $30 \mathrm{~cm}, 50,150$ and $450 \mathrm{~cm}$ downstream the profile sampling points, resembling horizontal sections $(0-15 \mathrm{~cm}$ of depth), allow for describing chemical heterogeneity. Terrestrial background sediments were collected close-by the wetlands $(0-15 \mathrm{~cm}$ of depth).

All substrate samples were physically preserved in darkness at minus $20{ }^{\circ} \mathrm{C}$. For sediment analytics and extractions, aliquots were defrosted gently, thoroughly homogenised, oven-dried $\left(60{ }^{\circ} \mathrm{C}\right)$ to weight constancy, and ground with ceramic mortar and pestle to analytical size.

From each wetland, five characteristic plant species were collected, thoroughly brushed with deionised water and dried at room temperature. Roots were separated from shoots and leafs, each part homogenised by grinding with an electric mill.

\subsection{Analytical methodology and standards}

Chemical analyses of water, plant and sediment samples were done at the hydrochemical laboratory of the Institute of Earth Sciences, FSU Jena. The surface water samples were titrated instantly for $\mathrm{CO}_{3}$ and $\mathrm{HCO}_{3}$ (Metrohm, Titrino 716 DMS, Germany). Major elements were analysed by ICP-OES (Spectro, Germany), trace elements additionally by ICP-MS (Merchantek/VG Elemental, USA) with external multi element standard calibration and internal precision determined by 3 to 4 runs on the samples (as relative standard deviation RSD). The (earth) alkali ions $\mathrm{Na}, \mathrm{K}, \mathrm{Ca}$ and $\mathrm{Mg}$ were measured using ion chromatography (Dionex, DX120/DX600, USA), as well as $\mathrm{SO}_{4}, \mathrm{Fe}, \mathrm{Mn}, \mathrm{Al}$ and $\mathrm{Cr}$ with atomic absorption spectroscopy (Analytik Jena, AAS 5EA, AAS 5FL, Germany). Photometric titration was applied for anions $\mathrm{NO}_{3}, \mathrm{NO}_{2}$ and $\mathrm{PO}_{4}$ (Hach, $D R / 4000 \mathrm{~V}$, Germany). Determination of $\mathrm{Fe}(\mathrm{II})$ was carried out with UV-visible spectroscopy (Hach, FerroVer method, Germany). Dissolved 
organic carbon DOC was analysed on $<45 \mu \mathrm{m}$ filtered water samples (Dimatec, DIMA-TOC 100, Germany).

Physicochemical parameter measurement was applied by using portable instruments (WTW Co., Germany) with single-rod measuring cells for $\mathrm{pH}$ (WTW $\mathrm{pH} 330$, two-point calibration), and electric conductivity (WTW Lf 330).

For sediment elemental analyses, dried samples were digested in concentrated $\mathrm{HF}, \mathrm{HClO}_{4}$ and $\mathrm{HNO}_{3}$ (in a ratio of $1.5: 1.5: 1$ ), heated to $190{ }^{\circ} \mathrm{C}$ for 12 hours, and taken to dryness on a heating block. The residue was then leached $\left(2 \mathrm{~mL} \mathrm{HNO}_{3}, 0,6 \mathrm{~mL} \mathrm{HCl}\right)$ and diluted with deionised water to a volume defined and analysed by ICP-OES and ICP-MS. Generally, regarding instrument precision, the deviation was better than $5.1 \%$ for major elements and $16.0 \%$ for trace elements, besides of As $(33.6 \%)$.

The organic carbon concentration (OC), total carbon $\mathrm{TC}$, total nitrogen $\mathrm{TC}$ and total sulphur TS in the sediments were determined by dry combustion at $950{ }^{\circ} \mathrm{C}$, using a Vario EL CNS element analyser (Elementar Analysensysteme GmbH, Heraeus, Germany) with extern solid standard calibration. Here, the inorganic carbon TIC was determined by difference measurement after digestion of TIC. As substrate samples from Zinnborn (WLZ) were rich on longish, not grindable macrophytic fragments which were byoing upwards in the digestion solution, these fragments were removed improperly before OC measurement. Consequently, the inorganic carbon content was determined using the Scheibler method (DIN 18129, 1990), converting $\mathrm{CO}_{2}$ volume to TIC (calculated as calcite minerals).

A seven-step sequential chemical extraction procedure followed a description of Miller et al. (1986), modified after Batson et al. (1996). Sowder and Bertsch (2002) verified the specificity of the method by direct $U$ speciation in their samples using X-ray fluorescence and spectrometric methods (SXRF, XANES). The details of the procedure have been given by Sowder et al. (2003). According to this and in contrast to the protocol from Batson et al. 
(1996), one step ('bound to Mn oxides') was skipped. The extraction was carried out progressively on an initial weight of $0.75 \mathrm{~g}$ of the profile substrate material. The extractants used are listed from least to most aggressive in Table 3, as well as the operationally defined phases affected by each. After each extraction step a cleaning step (45 min.) was inserted. The cleaning solutions $\left[0.025 \mathrm{M} \mathrm{Ca}\left(\mathrm{NO}_{3}\right)_{2}\right]$ were discarded (Sowder et al., 2003). Extraction solutions were analysed by ICP-MS $(n=3)$; results for uranium are presented below. Regarding instrument precision, the deviation for uranium was better than $5 \%$ for $96 \%$ of the entire samples. Sequential extractions of duplicate samples from one horizon supply similar uranium partitioning whilst the bulk concentration varies noticeably within two aliquots (up to $14 \%$ RSD).

Plant samples were processed in fuming $\mathrm{HNO}_{3}$ in a closed-vessel microwave digestion (CEM, Mars 5, Germany) and analysed by ICP-OES and ICP-MS.

For plant and sediment digestion and extraction, respectively, accuracy was controlled by processing standard reference material (IAEA-SOIL-7) and sample duplicates or triplicates. Corrections were made using blank values of the pure chemicals. All chemicals were analytical grade and, besides $\mathrm{HF}$, with additional distillation.

\subsection{Correlation techniques on elemental analyses}

The statistical evaluation of pore water data was executed through Spearman rank correlation and linear regression assessment. It was aimed primarily at associations of $U$ and potential ligands, such as $\mathrm{CO}_{3}$ and $\mathrm{OC}$ which may be important at the prevailing circumneutral $\mathrm{pH}$ values. Secondly, measured data were normalised to the concentrations of refractory elements, i.e., Si in case of dissolved concentrations, trying to elucidate alterations of pore water chemistry. Normalising each single substrate element to refractory $\mathrm{Zr}$ may enable to depreciate influences deduced from background concentrations. 


\section{RESULTS}

\subsection{Water}

The ion load of the water samples (Table 4) is represented by a very high electric conductivity (mean 1.37 to $3.18 \mathrm{mS} / \mathrm{cm}$ ). Pore water uranium concentrations (Table 1) have median values of $0.7 \mathrm{mg} / \mathrm{L}$ in Helmsdorf, $1.9 \mathrm{mg} / \mathrm{L}$ in Culmitzsch and $0.4 \mathrm{mg} / \mathrm{L}$ in Zinnborn. In Culmitzsch, the surface water on top of the sampled profile displays the highest uranium concentration of $6.2 \mathrm{mg} / \mathrm{L}$. Regarding metals which may interfere with uranium, Mn concentrations ( $\leq$ $13.3 \mathrm{mg} / \mathrm{L}$ in Helmsdorf, $\leq 5.6 \mathrm{mg} / \mathrm{L}$ in Culmitzsch) are noticeable. Fe concentrations are low. Sulphate concentrations rise up to $2000 \mathrm{mg} / \mathrm{L}$ in Helmsdorf, $3192 \mathrm{mg} / \mathrm{L}$ in Culmitzsch, and $426 \mathrm{mg} / \mathrm{L}$ in Zinnborn. From major anion proportions, the water of Helmsdorf has been classified as a calcium-sodium-sulphate chemical type with a $\mathrm{pH}$ ranging from 6.5 to 8.0 and a surface water alkalinity of $572 \mathrm{mg} / \mathrm{L} \mathrm{HCO}_{3}$ (very hard). Culmitzsch provides a sodiumsulphate water with a $\mathrm{pH}$ ranging from 7.1 to 8.2 and an alkalinity in the range of $832 \mathrm{mg} / \mathrm{L}$ $\mathrm{HCO}_{3}$ (very hard), the latter deduced from surface water. In Zinnborn, a sodium-sulphatechloride chemical type with a $\mathrm{pH}$ ranging from 6.4 to 6.9 and a surface water alkalinity of 191 $\mathrm{mg} / \mathrm{L} \mathrm{HCO}_{3}$ (hard) was determined. Culmitzsch provides an aquatic organic content with mean $16.8 \mathrm{mg} / \mathrm{L}$ DOC, Zinnborn with mean $19.6 \mathrm{mg} / \mathrm{L}$, and Helmsdorf with mean $34.4 \mathrm{mg} / \mathrm{L}$.

\subsection{Plants and sediments}

Plant grown on the substrates show intercellular U concentrations ranging from 20 (Carex) to 400 (Characea) $\mathrm{mg} / \mathrm{kg}$ root dry mass (values not displayed). In the shoots, U concentrations are clearly much lower, from 5 (Eleocharis) to 100 (Characea) $\mathrm{mg} / \mathrm{kg} \mathrm{U}$ on a dry mass base. Wetland substrates from temporarily or permanently flooded environments normally consist of semiterrestrial to subhydric soils, which are sediments in a geological term. In the case of 
Helmsdorf and Zinnborn hydromorphic soils with peat mosses are developed as histic gleysols to histo-humic gleysols, and subhydric soils (sapropel) in Culmitzsch (compare Table 1). Many of the inorganic components are rock fragments derived from tailing ponds, as well as primary and secondary minerals, suspected from authigenic sources and particulate transport. X-ray diffraction analyses (XRD) confirmed the presence of abundant quartz, secondarily in many strata clay minerals (illite, chlorite and/or kaolinite) and feldspar (Schöner, 2006). In Helmsdorf, also pyrite and calcite are detectable, the latter near-surface. With this method uranium could not be proven to be present in any of the samples.

Mean Fe concentrations in Helmsdorf are around $50000 \mathrm{mg} / \mathrm{kg}$, in Culmitzsch 4500 and Zinnborn $8000 \mathrm{mg} / \mathrm{kg}$ (Table 6). Just the same high concentrations were analysed for the metals Mn (maximum $18.5 \mathrm{~g} / \mathrm{kg}$ in Helmsdorf) and $\mathrm{Al}$ (max. $95 \mathrm{~g}$ in Culmitzsch and $109 \mathrm{~g} / \mathrm{kg}$ in Zinnborn). Uranium in substrate samples of Helmsdorf has a mean concentration of $389 \mathrm{mg} / \mathrm{kg}$, ranging from 4 to $1117 \mathrm{mg} / \mathrm{kg}$. Culmitzsch substrate samples have a mean U concentration of $182 \mathrm{mg} / \mathrm{kg}$, ranging from 62 to $443 \mathrm{mg} / \mathrm{kg}$. Zinnborn substrate samples with mean $\mathrm{U}$ concentration of $2104 \mathrm{mg} / \mathrm{kg}$ range from 152 to $7562 \mathrm{mg} / \mathrm{kg}$.

The measured OC concentrations of the wetlands are elevated (mean $12 \mathrm{wt}-\%$, maximum 26 wt-\%), but clearly below histosols typical for wetlands (48-53 wt-\%; Naucke, 1974). The different strata of Helmsdorf show 1-20 wt- $\%$ of OC, of Zinnborn 8-26 wt-\%, and of Culmitzsch only 1-3 wt-\% (Table 7). Provided that OC is stabilised completely in humic substances, organic matter may rise up to $51 \mathrm{wt}$ \% (Zinnborn). Helmsdorf displays the highest concentrations of total S (mean $1.7 \mathrm{wt}-\%$ ) and $\mathrm{N}$ (mean $1 \mathrm{wt}-\%$ ). Again in Culmitzsch, $\mathrm{S}$ concentrations are half as much, in Zinnborn only one third. The atomic ratio of organic $\mathrm{C}$ to S (atomic weight proportions, compare Friese et al., 1998) is very narrow in Culmitzsch (3 to 10), relatively narrow in Helmsdorf (10 to 26$)$ and particularly wide in Zinnborn (C/S from 73 to 116$)$. The $\mathrm{C} / \mathrm{N}$ ratios are wide in Zinnborn (25 to 34) and narrow in Culmitzsch (11 to 17). 
Substrate samples from near-surface horizontal sections, following the flow path of each wetland, show narrow structural differences, but relatively high fluctuations for elemental compositions (data not shown). No distinct concentration trends were found, which may deduce water amelioration. Yet, regarding the sampled substrates from vertical and horizontal sections, elemental concentrations inside each wetland are in the same range, resembling internal distribution and concentration tendencies. Terrestrial sediments close-by the wetlands Culmitzsch and Zinnborn, unaffected from wetland environment, have much lower U concentrations (Culmitzsch: < $20 \mathrm{mg} / \mathrm{kg}$; Zinnborn: $62 \mathrm{mg} / \mathrm{kg}$ ). Solid phase $\mathrm{U}$ is high concentrated $(360 \mathrm{mg} / \mathrm{kg})$ in the background sample from Helmsdorf.

\subsection{Correlation}

In water samples of Helmsdorf, only weak positive correlations were found (Table 5) between $\mathrm{U}$ and $\mathrm{SO}_{4}\left(\mathrm{r}_{\mathrm{S} \text {, normalised }}=0.36\right)$ and $\mathrm{Cl}$, respectively $\left(\mathrm{r}_{\mathrm{S} \text {, normalised }}=0.43\right)$. A positive correlation between $\mathrm{U}$ and $\mathrm{PO}_{4}\left(\mathrm{r}_{\mathrm{S}}\right.$, normalised $\left.=0.60\right)$ was found in Culmitzsch. In Zinnborn, for U there are strong positive correlations to $\mathrm{F}\left(\mathrm{r}_{\mathrm{S}}\right.$, normalised $\left.=0.82\right), \mathrm{DOC}\left(\mathrm{r}_{\mathrm{S}}\right.$, normalised $\left.=0.77\right)$, and to a lesser extent $\mathrm{SO}_{4}\left(\mathrm{r}_{\mathrm{S}, \text { normalised }}=0.61\right)$ and DIC $\left(\mathrm{r}_{\mathrm{S}}\right.$, normalised $\left.=0.51\right)$, respectively.

Normalised substrate data for Helmsdorf and for Zinnborn show comparable Spearman rank correlation arrays (data not shown) with high $\left(\mathrm{r}_{\mathrm{s}, \text { normalised }}>0.70\right)$ or very high $\left(\mathrm{r}_{\mathrm{s}}\right.$, normalised $>$ 0.90) correlation coefficients for most of the elements. For U, in Helmsdorf generally high correlation coefficients were calculated, the highest with Fe and $\mathrm{Mn}\left(\mathrm{r}_{\mathrm{s}}\right.$, normalised $\left.>0.98\right)$. Uranium and OC are strongly correlated $\left(\mathrm{r}_{\mathrm{s} \text {, normalised }}=0.79\right)$ only with normalised data. From high correlation coefficients of non-normalised data $\left(r_{s}>0.86\right)$, in Helmsdorf strong interrelations are deduced for $\mathrm{U}$ to $\mathrm{Cu}$ and $\mathrm{Mg}$, respectively, and weak correlations for $\mathrm{U}$ to most heavy metals. Regarding non-normalised data, in Zinnborn $U$ is strongly correlated with $\mathrm{Ca}\left(\mathrm{r}_{\mathrm{s}}=0.93\right)$, and $\mathrm{Cd}$ as well as $\mathrm{P}\left(\mathrm{r}_{\mathrm{s}}>0.79\right)$. When normalising the substrate elemental concentrations to $\mathrm{Zr}$, for Zinnborn some elements are less strongly correlated, e.g., U and Al. 
There is a strong correlation U/OC both with normalised and non-normalised concentrations $\left(\mathrm{r}_{\mathrm{s}}>0.82\right)$. In contrast for U/TIC, a weak correlation is obvious only when regarding the nonnormalised data $\left(r_{\mathrm{s}}=0.50\right)$. Noticeable, while non-normalised data reveal no relation of $U$ to $\mathrm{Fe}$, these elements are completely correlated regarding normalised data $\left(\mathrm{r}_{\mathrm{s}}=1.00\right)$. In Wetland Culmitzsch $\mathrm{U}$ is strongly positively correlated to $\mathrm{Cr}$ and $\mathrm{Cd}\left(\mathrm{r}_{\mathrm{s}}>0.87\right)$, as well as negatively to $\mathrm{As}, \mathrm{Ni}, \mathrm{Ba}, \mathrm{Ca}\left(\mathrm{r}_{\mathrm{s}}=-0.80\right)$. Here, only small differences occur between normalised and non-normalised correlation coefficients.

\subsection{Sequential extraction of uranium}

Diagrams in Figure 2 sum up the percent of $U$ in the different extraction steps, in vertical profiles displaying the substrate $U$ distribution for each strata. The graphical display of relative amounts was preferred, since this study largely focuses on the $U$ distribution in different extraction steps and not on the total release.

Uranium is predominantly distributed in the very labile (water soluble, exchangeable) and moderately labile fractions (acid soluble and organically bound). The organically bound fraction is particularly dominant in Zinnborn and Helmsdorf (47-64 wt-\% of total $\mathrm{U}$ on average). These are the wetlands with a higher amount of organic carbon (OC up to $26 \mathrm{wt}-\%)$. However, no correlation between OC and the organically bound uranium was found. In strata consisting of moderately degraded peat mosses (approx. 5 to $20 \mathrm{~cm}$ below surface in Helmsdorf and up to $60 \mathrm{~cm}$ of depth in Zinnborn), $\mathrm{U}$ was liberated in large portions in the pyrophosphate extraction step for organics (up to $77 \mathrm{wt}-\%$ of total $\mathrm{U}$, ranging from 60 to $6100 \mathrm{mg} / \mathrm{kg} \mathrm{U}$ ). One of the peat horizons contradicts this partitioning in liberating elevated $\mathrm{U}$ portions in the exchangeable fraction, whereas only $27 \mathrm{wt}-\%$ of total $U$ are organically bound. Only a small percentage of uranium is stored as 'residue' in Helmsdorf and Zinnborn, with the exception of two strata in Helmsdorf (WLHe8, WLHe10) which generally show very low 
bulk U concentrations $(<5 \mathrm{mg} / \mathrm{kg}$, compare Table 7). Similarly, in one strata of Zinnborn $43 \mathrm{wt}-\%$ of $\mathrm{U}$ are stored as 'residue'.

Culmitzsch contains $2 \mathrm{wt}-\%$ of OC on average, compared to $10 \mathrm{wt}-\%$ of $\mathrm{U}$ released from the 'organically bound' soil fraction. In the uppermost strata, most of the uranium is distributed in very labile phases (31 wt- $\%$ water soluble, $33 \mathrm{wt}-\%$ exchangeable on average). The sediments between 15 to $40 \mathrm{~cm}$ depth comprise only low $U$ concentrations $(<100 \mathrm{mg} / \mathrm{kg})$, which are distributed in the 'residue' fraction (up to $44 \mathrm{wt}-\%$ increasing with depth).

Sequential extraction results for the reference soil (IAEA-SOIL-7, values not displayed) are very different from those for the wetland sediments. The uranium in the reference soil results from host rock weathering and appears mostly as 'residue' ( $72 \mathrm{wt}-\%$ ), followed by organically bound U (11 wt-\%).

\section{DISCUSSION}

\subsection{Environmental conditions pertaining to $U$ accumulation}

The general chemical input to the wetlands is governed by various sources and pathways. In terms of uranium retention in the substrates, particulate species facilitate a more stable fixation, whereas entrapment of aqueous (dissolved or colloidal) species not necessarily is followed by immobilisation processes.

The investigated wetland pore waters show characteristics of tailing drainage from sodaalkaline uranium leaching (compare 2.2), with very high electric conductivity, circumneutral $\mathrm{pH}$ and elevated concentrations of $\mathrm{Na}$ and $\mathrm{SO}_{4}$. Similarly, the wetland substrates mirror elemental spectra deducible from the tailings, i.e. ore milling residues and silica rich overburden. Aqueous transport with in situ precipitation is assumed as an important pathway, especially for pollutants which are mobile at circumneutrale $\mathrm{pH}$ values. Thereby, elevated pore water concentrations of the anions $\mathrm{SO}_{4}$ (Helmsdorf and Culmitzsch), $\mathrm{Cl}$ (Helmsdorf) and 
$\mathrm{NO}_{3}$ (Zinnborn) are bearing a risk for undesirable $\mathrm{U}$ re-mobilisation and dissemination through aqueous complexation (compare 5.2). The same applies to elevated $\mathrm{HCO}_{3}$ concentrations in the former two, and DOC in all three wetlands. They are rich in DOC (mean 16.8 to $34.4 \mathrm{mg} / \mathrm{L})$, comparable to typical DOC in bogs $(10$ to $50 \mathrm{mg} / \mathrm{L})$ and in contrast to common groundwater DOC (0.5 to $1.5 \mathrm{mg} / \mathrm{L}$ ) (Sigg and Stumm, 1995).

However, the refractory $\mathrm{Ti}$ in a concentration range of major elements indicates a certain airborne/waterborne particle input or even input from underground weathering. Comparable correlation coefficient arrays for substrate elements of Helmsdorf and Zinnborn corroborate a composition resembling a primary solid phase composition, deducible either from particulate input or host rock weathering. Additionally, the rank correlation technique suggests some importance of environmental conditioning for Zinnborn. In this wetland, new formation of humic substances can be deduced from the calculated organic $\mathrm{C} / \mathrm{N}$ and $\mathrm{C} / \mathrm{S}$ ratios (Nriagu and Soon, 1985; Scheffer and Schachtschabel, 2002), and to a less extent in Helmsdorf. Soil formation makes a minor contribution to the substrates in Culmitzsch. Here, the $\mathrm{C} / \mathrm{S}$ ratio points to irrelevance of organic C-S or C-O-S bonds (Nriagu and Soon, 1985), whereas the relatively low OC content rather suggests major minerogenic input of $\mathrm{C}, \mathrm{N}, \mathrm{S}$ and $\mathrm{O}$ (Hakanson and Jansson, 1983). Generally, wetland Culmitzsch provides different elemental relations in each strata, probably indicating alterations in input pathways.

\subsection{Uranium distribution and correlation}

Regarding uranium, tailing material is the only contamination source in Helmsdorf and Zinnborn, though with various input pathways. In Culmitzsch in situ bedrock weathering may contribute via uraniferous host rock. Secondary U enrichment in the wetlands is emphasized by comparing to the local background. The terrestrial sediments close to the wetlands Culmitzsch and Zinnborn exhibit less than $11 \%$, and $3 \%$ respectively, of the mean U 
concentrations in the wetland substrates. For wetland Helmsdorf, background and substrate samples with analogous $U$ concentrations suggest a major importance of air-transported particles from the tailing ponds.

Uranium maximum concentrations in the pore waters were determined with $4.7 \mathrm{mg} / \mathrm{L}$, and with $6.2 \mathrm{mg} / \mathrm{L}$ in the surface water. Although in Helmsdorf $\mathrm{U}$ is correlated to $\mathrm{SO}_{4}$ and $\mathrm{Cl}$, these anions are not relevant as complexing agents at the $\mathrm{pH}$ values measured. For Culmitzsch in the near-surface strata, formation of uranyl phosphate complexes can be assumed. $\mathrm{As}^{\mathrm{PO}_{4}}$ concentrations are very low, it is not regarded an important pathway for $\mathrm{U}$ transport. In Zinnborn carbonate complexes may have contributed to uranium input, as well as humic complexes to some extent. Again, the correlation of $\mathrm{U}$ to $\mathrm{SO}_{4}$ and to $\mathrm{F}$ is not indicative for transport in complexes, since $\mathrm{pH}$ is not in the right range. Altogether, the statistical evaluation of the data set indicates that, besides a minor interrelation of $\mathrm{U}$ and (organic) $\mathrm{C}$ in Zinnborn, prevailing processes which may influenced the fait of aqueous uranium in the three wetlands cannot be elucidated.

The mean U concentrations in the substrate samples of Zinnborn $(2104 \mathrm{mg} / \mathrm{kg})$ are 5-times higher than of Helmsdorf $(389 \mathrm{mg} / \mathrm{kg})$ and exceed Culmitzsch 6.5 -times $(182 \mathrm{mg} / \mathrm{kg})$. In Zinnborn, the strata rich in OC (WLZ1 to WLZ4, compare Table 2) expose enormous high uranium enrichment with maximum values of almost $1 \mathrm{wt}-\%$, i.e., $\leq 10000 \mathrm{mg} / \mathrm{kg}$ of $\mathrm{U}$ in dry mass. Organic carbon may provoke U accumulation primarily through in situ complexation, but not exclusively. In comparing normalised to non-normalised data, for Zinnborn the high U/OC correlation suggests some importance of biosorption or bioaccumulation processes, or even formation of humic substances. Correlation of U to TIC possibly points at solid inorganic uranyl carbonate complexes. In Helmsdorf, a high correlation for $\mathrm{U}$ and $\mathrm{OC}$ (normalised data) seems to reveal linear relations deducible from the geogenic input, implying 
refractory organic matter in substrate particles. A possible source is the ore-extraction waste derived from U-rich hard coal, which was mined in the Dresden-Freital area.

The deduced primary relation $\mathrm{U} / \mathrm{Fe}$ (normalised to $\mathrm{Zr}$ ) in Zinnborn could not be proven with any of the geochemical investigations, including sequential extraction (see 5.3). Regarding U in Culmitzsch, no trends with depth or environmental conditioning are indicated. Interestingly, none of the wetlands reveals statistical interrelations between non-normalised values for $\mathrm{U}$ and $\mathrm{Fe}$ or $\mathrm{Mn}$ as a possible effect of secondary sorption or co-precipitation processes. This is in contrast to literature presumptions on the importance of these processes (e.g., Klessa, 2000). Similar, there is no clear relation U/OC regarding the entire wetland substrate samples. However, there is evidence to suggest a complex interrelation between uranium and organic carbon content. Only at higher concentrations, solid OC and U are correlated linearly and positively, indicating an involvement of $\mathrm{OC}$ in the accumulation processes.

Nevertheless, clearly prevailing processes for $U$ retention could not be elucidated. This implies that there is no dominant uranium association with special ligands in the sediments, that might dispose inorganic bonds to $U$ or meet the same fate in the substrates. In particular, from bulk chemical data there is no dominance of a single process like sorption to $\mathrm{Al}$ hydroxides or coprecipitation with Fe minerals, leading to the high $\mathrm{U}$ substrate concentrations. Instead of that, several processes contribute to uranium fixation.

Most of the measured contaminants in the substrates, notably concerning U, As and different metals $(\mathrm{Zn}, \mathrm{Cu}, \mathrm{Pb}, \mathrm{Cd}, \mathrm{Mo})$ show concentration maxima in the upper parts of the investigated profiles. Regarding uranium vertical allocation, it is noticeable that the highest concentrations occur in approximately 5 to $25 \mathrm{~cm}$ of substrate depth, proportional decreasing up to 75 to $90 \%$ below that horizon. The vertical $\mathrm{U}$ distribution is independent of OC content or macroscopic consistency. In wetland Helmsdorf the organic matter content (mean 25 wt-\%) 
increases to the depth of strata WLHe8 (41 wt-\%), with a noticeable decline till WLHe10. In wetland Zinnborn, the elements with major organic binding fractions $(\mathrm{C}, \mathrm{N}, \mathrm{S}, \mathrm{P})$ are distinctive accumulated up to $45 \mathrm{~cm}$ of depth (WLZ1 to WLZ4, mean $35 \mathrm{wt}-\%$ organic matter), similar to predominant Sphagnum spp. mosses. These observations lead to the assumption that, between water and wetland substrate, a contact zone of intensive exchange is limited to horizons close to the surface, implying a distinct flow pattern. From natural wetlands, uranium accumulations limited to near-surface sediments are described repeatedly (Pardi, 1987; Tixier and Beckie, 2001), and similarly, the retention of $\mathrm{Ni}$ and Co from mining stockpile leachate (Eger and Lapakko, 1988). The preferential reaction zone within the peat layer of Zinnborn may result from ponding groundwater in deeper parts which is limited to diffusive exchange, whereas in the upper parts a convective exchange is suggested, causing higher fluctuations in elemental composition. Results from several investigations support this suggestion (Schöner, 2006).

\subsection{Uranium fractionation and possible speciation}

Uranium distribution is inferred from an operationally defined sequential extraction procedure. The step-wise sequence (compare Table 3) stands for increasing bonding strength of $U$ to the soil, which to some extent may be attributed to different processes - like sorption or incorporation into Fe oxides or even reductive U precipitation. Stable U(IV) minerals (i.e., crystalline) are soluble only in the last extraction step ('residue'), while digested with HF. The amount of available $U$ therefore indicates the sensibility of the ecosystem for seasonal variations or otherwise induced fluctuations, e.g., variations in discharge input.

Uranium is partitioned in different compartments of the substrates, including both minerogenic and biotic reservoirs, the latter comprising macrophytes and micro-organisms. In the organic rich strata of Zinnborn and Helmsdorf, uranium is predominantly associated with the organic soil fraction. While digested with sodium pyrophosphate at high $\mathrm{pH}$, uranium was 
mobilised simultaneously. Obviously, uranium is bound relatively weakly and therefore resolubilises, e.g., when the mosses are further degraded by micro-organisms. In comparison to the high amount of organically bound $U$ in the substrates, sampled plant species growing directly on the wetland substrates have an average $U$ content less than $12 \mathrm{wt}-\%$ of that of the wetlands substrates, suggesting that living plant material is not responsible for the enrichment of uranium in these wetlands. Our phytoextracted $U$ concentrations are in the range of typical literature data (e.g., Vandenhove et al., 2006). Of the measured root concentrations, values from Urtica and Characeae are clearly above-average, yet not signifying uranium hyperaccumulation. Calculated transfer factors from root to shoot range from 0.09 to 0.51 and are relatively high as compared to typical data from controlled down-scaled experiments (Bergmann et al., 2006).

Results from sequential extraction demonstrate, that in strata with less OC, the exchangeable or acid soluble fraction is more significant, implying uranium adsorption or solid phase complexes. This uranium fraction can easily be re-mobilised if environmental conditions change. Regarding the more sustainable process of uranium accumulation in the residual phase, particulate transport or in situ precipitation of uranium minerals are to be considered, as discussed earlier. If at all, reductive precipitation of secondary uranium minerals may have occurred to a very small extent, as appropriate redox conditions have not yet been established in the wetlands. Uranium minerals were not detectable with SEM/EDX, XRD or XPS (Schöner, 2006).

Wetland Culmitzsch contains little uranium and OC. Regarding redox conditions and SI calculations, this wetland comprises good conditions for sulphate reduction, especially as compared to the other wetlands. Therefore, from dissolved uranium entering the wetland the precipitation of U(IV) minerals is likely. However, according to sequential extraction, mainly small amounts of $U$ in the 'residue' indicate uranium reduction and mineralisation. Despite 
generally low $U$ contents the relative importance of residual uranium fixation increases in the deeper strata $(15-40 \mathrm{~cm})$, with simultaneous decrease of more labile $\mathrm{U}$ fractions. This may indicate diagenetic redistribution in more stable phases. However, it is more likely that mobilisable uranium is washed out from the substrates, especially in deeper strata as underlain with more porous sediments, resulting in relative enrichment of residual uranium. Altogether, in Culmitzsch the high extraction of uranium in the water soluble fraction has negative implications for transport, bioavailability, and toxicity. At least the relatively high represented acid soluble fraction may include $U$ carbonate minerals or other $U$ phases specifically sorbed, e.g., to clay minerals. Despite the favourable redox environment, the entire observations for wetland Culmitzsch contradict any effectiveness in long-term uranium fixation.

Generally, from sequential extraction of uranium in wetland soils and similar sediments, both literature data and the results in this study demonstrate, that moderately labile fractions mostly prevail (Figure 2). Different sequential extraction procedures were surveyed, carried out to determine partitioning of uranium in soils or sediments (Table 8). Kaplan and Serkiz (2001) and Sowder et al. (2003) employed a modified Miller extraction protocol as used in this study, thereby revealing data for $U$ fractionation similar to this study, and as well from wetland sediments.

Coetzee et al. (2002) found most uranium bound to $\mathrm{FeOOH}$ and $\mathrm{MnO}_{\mathrm{x}}$ complexes, indicating a less weak association. On the other hand, they used extractants which did not enforce such distinct $\mathrm{pH}$ shifts as the modified Miller protocol. Sowder et al. (2003) supposed for the Miller protocol, that the application of pyrophosphate to dissolve organics at $\mathrm{pH} 10$ may release uranium phases aggressively and presumably non-specific. As this is not disproved so far, it is to keep in mind that the organic phase may have been overestimated.

More stable associations were mostly found in sediments not comparable to wetland substrates, since, e.g., river sediments or spoil heap material may contain less OC, but distinct 
amounts of alluvial deposits including uranium mineral phases. Only for marine sediments (Schultz et al., 1998), strong reducing conditions are self-evident, demonstrably resulting in precipitation of $\mathrm{U}(\mathrm{IV})$ minerals.

From the applied sequential extraction procedure it can be concluded that in none of the investigated wetland profiles significant amounts of uranium are immobilised in stable phases, but may rather be available to the aquatic environment under changing conditions. Uranium is accumulated mainly due to physical adsorption or specifical sorption (complexing reactions). The varying results also indicate that in the surveyed wetlands uranium is bound to multiple sites, for some horizons in approximately equal quantities, so that any environmental change resulting in $\mathrm{pH}$ shifts could release uranium, as simulated in different chemical extraction steps. (Bio-)chemical reduction does not seem to be essential for the high uranium accumulation.

\section{CONCLUSIONS - PROPOSAL FOR URANIUM RETENTION PROCESSES IN WETLANDS}

Undoubtedly, the role of wetland substrates is connected to organisms, providing physical and chemical remediation effects. Field and laboratory studies suggest the minor importance of macrophytes by means of phytoextraction processes. Phytoremediation concepts in wetlands may act as a temporary uranium sink and may increase the transfer to solid state. In wetlands with toxic elements, rhizostabilisation is the solely favoured contribution via bioaccumulation by plant roots (Raskin et al., 1994). However, usually up to 99 wt- $\%$ of the retained uranium and metal contaminants are located in the substrate and not incorporated into the plant material (Eger and Lapakko, 1988 and references herein; Eger and Wagner, 2003). 
Nevertheless, macrophytes mainly contribute indirectly to wetland systems, via rhizosphere effects (compare Schöner, 2006), and directly in providing compost material.

Cation exchange on such solid organic material, e.g., Sphagnum moss as a major wetland plant species and substrate component, is very effective in uranium sorption (e.g., Titayeva, 1967). This was consistently confirmed via sequential extraction procedures, which were successfully applied on wetland substrates, e.g., in this study. The results of these procedures repeatedly indicate a high lability of uranium (compare 5.3). As only few percents of uranium are frequently extractable with water, it is obvious that chemical processes largely supplement the physical entrapment. However, only few percents of the bulk uranium concentrations are stable retained in solid phases. In none of the investigated wetlands and literature studies, (bio-)reduction of uranium could be confirmed as principal or even important retention process, although often estimated.

This observation implies accumulation mechanisms that are affected by environmental changes, like sorption to organic substrate components. Therefore it is obvious, that external disturbances in wetland systems (e.g., seasonal or hydrological fluctuations, changes in $E_{H}$ or $\mathrm{pH}$ values, or varying microbiological activities) may release uranium from wetland sediments. Biosorbed uranium may be released if the biomass is degraded.

Nevertheless, from high uranium enrichment factors in the examined natural wetland substrates it is to assume, that several processes contribute to their effectiveness, finally enabling sustainable storing mechanisms. The initially loosely entrapped uranium may be transferred into more stable species. Concrete indices for this assumption where found in applying advanced geochemical methodologies and analytical methods (Schöner, 2006). 


\section{ACKNOWLEDGEMENTS}

Wetland sampling was kindly authorised by Wismut GmbH / Wisutec GmbH. This study was partly supported by Thuringia's Ministry of Culture. ICP-MS and ICP-OES measurements were carried out by Dr. D. Merten and I. Kamp, and CNS analyses by C. Luge at the Institute of Geography, FSU Jena.

\section{REFERENCES}

Akber, R.A., Johnston, A., Hancock, G., 1992. Absorption of radionuclides and other solutes in a natural wetland system. Radiation Protection Dosimetry 45, 293-297.

Ames, L., McGarrah, J., Walker, B., Salter, P., 1983. Uranium and radium sorption on amorphous ferric oxyhydroxide. Chemical Geology 40, 135-148.

Baier, A., 2004. Geogene und anthropogene Beeinflussungen zweier naturnaher Fließgewässer am Südrand des Nürnberger Beckens. Geologische Blätter für NO-Bayern 54, 1-4, 101-168.

Ballenweg, S., 2005. RÖMPP online, CD Chemielexikon. Georg Thieme Verlag KG, Stuttgart.

Batson, V.L., Bertsch, P.M., Herbert, B.E., 1996. Transport of anthropogenic uranium from sediments to surface waters during episodic storm events. Journal of Environmental Quality 25, 11291137.

Beckers, N., 2005. Böden auf künstlichen und natürlichen Substraten der ostthüringischen Bergbaufolgelandschaft als Senken und Quellen bergbauinduzierter Stoffe (Dissertation Uni Regensburg), Regensburg, 418 pp.

Bergmann, H., Voigt, K.-D., Machelett, B., Gramss, G., 2006. Variation in heavy metal uptake by crop plants. In: Merkel, B.J., Hasche-Berger, A. (Eds.), Uranium in the environment - mining impact and consequences. Springer, Berlin, Heidelberg, pp. 459-468.

Berner, R.A., 1981. A new geochemical classification of sedimentary environments. Journal of Sedimentary Petrology 51, 359-365.

BfFR (2007): BfR empfiehlt die Ableitung eines europäischen Höchstwertes für Uran in Trink- und Mineralwasser.- Stellungnahme Nr. 020/2007 des BfR vom 5. April 2007, 46 S., http://www.bfr.bund.de/cm/208/bfr_empfiehlt_die_ableitung_eines_europaeischen_hoechstwe rtes_fuer_uran_in_trink_und_mineralwasser.pdf; Bundesinstitut für Risikobewertung (Berlin).

Braithwaite, A., Livens, F.R., Richardson, S., Howe, M.T., Goulding, D.W., 1997. Kinetically controlled release of uranium from soils. European Journal of Soil Science 48, 661-673.

Bruno, J., de Pablo, J., Duro, L., Figuerola, E., 1995. Experimental study and modeling of the U(IV)$\mathrm{Fe}(\mathrm{OH})_{3}$ surface precipitation/coprecipitation equilibria. Geochimica et Cosmochimica Acta 59, 4113-4123.

Coetzee, H., Wade, P., Winde, F., 2002. Reliance on existing wetlands for pollution control around the Witwatersrand gold/uranium mines of South Africa - Are they sufficient? In: Merkel, B.J., Planer-Friedrich, B., Wolkersdorfer, C. (Eds.), Uranium in the aquatic environment. Springer, Berlin, Heidelberg, pp. 59-64.

Cole, S., 1998. The emergence of treatment wetlands. Environmental Science and Technology 32, 218A-223A. 
Czegka, W., Hanisch, C., Müller, A., Zerling, L., Lohse, M., 1998. Bindungsarten von Schwermetallen in verschiedenen Sedimenttypen der Sedimentaufbereitungsanlage Kleindalzig bei Leipzig. Zeitschrift der Deutschen Geologischen Gesellschaft 148, 491-498.

Dhoum, R.T., Evans, G.J., 1998. Evaluation of uranium and arsenic retention by soil from a low level radioactive waste management site using sequential extraction. Applied Geochemistry 13, 415-420.

DIN 18129, 1990. Baugrundversuche und Versuchsgeräte: Kalkgehaltsbestimmung. Beuth Verlag $\mathrm{GmbH}$, Berlin.

Duff, M.C., Amrhein, C., 1996. Uranium(VI) adsorption on goethite and soil in carbonate solutions. Soil Science Society of America Journal 60, 1393-1400.

Duff, M.C., Hunter, D.B., Bertsch, P.M., Amrhein, C., 1999. Factors influencing uranium reduction and solubility in evaporation pond sediments. Biogeochemistry 45, 95-114.

Dybek, J., 1962. Zur Geochemie und Lagerstättenkunde des Urans. Zeitschrift für Erzbergbau und Metallhüttenwesen 14, 1-9.

Eger, P., Lapakko, K., 1988. Nickel and copper removal from mine drainage by natural wetland. In: American Society for Surface Mining and Reclamation (Ed.), Mine drainage and surface mine reclamation conference. American Society for Surface Mining and Reclamation, Pittsburgh, PA, pp. 301-309.

Eger, P., Wagner, J., 2003. Wetland treatment systems - how long will they really work? In: Spiers, G., Beckett, P., Conroy, H. (Eds.), Sudbury 2003 - Mining and the Environment, Sudbury, United Kingdom, http://www.X-cd.com/sudbury03/.

Friese, K., Wendt-Potthoff, K., Zachmann, D.W., Fauville, A., Mayer, B., Veizer, J., 1998. Biogeochemistry of iron and sulfur in sediments of an acidic mining lake in Lusatia, Germany. Water, Air \& Soil Pollution 108, 231-247.

Gabriel, U., Gaudet, J.P., Spadini, L., Charlet, L., 1998. Reactive transport of uranyl in a goethite column: An experimental and modelling study. Chemical Geology 151, 107-128.

Gerth, A., Böhler, A., Kiessig, G., Küchler, A., 2000. Passive biologische Behandlung von Bergbauwässern. In: WISMUT 2000 (Eds.), Bergbausanierung, Schlema. Wismut GmbH, Chemnitz, Deutschland, pp. 1.

Groudev, S.N., Bratcova, S.G., Komnitsas, K., 1999. Treatment of waters polluted with radioactive elements and heavy metals by means of a laboratory passive system. Minerals Engineering 12, 261-270.

Groudev, S.N., Georgiev, P.S., Spasova, I.I., Angelov, A.T., Komnitsas, K., 2000. A pilot-scale passive system for the treatment of acid mine drainage. In: Nath, B., Pelovski, Y., Stoyanov, S.K. (Eds.), Sustainable solid waste management in the southern Black Sea region. Kluwer Academic Publisher / Springer, Dordrecht u. a., pp. 189-194.

Gruau, G., Dia, A., Olivie-Lauquet, G., Serrat, E., 2000. The effects of organic matter and seasonal redox dynamics on chemical weathering: Constraints from natural wetland studies. Journal of Conference Abstracts 5, 463.

Hakanson, L., Jansson, M., 1983. Principles of lake sedimentology. Springer, Berlin, Heidelberg, 316 pp.

Hallett, C.J., Lamb, H.M., Payne, C.A., 1997. The potential use of passive treatment technology for the removal of uranium from minewaters - an assessment of solid-aqueous equilibria. In: Younger, P.L. (Ed.), Minewater treatment using wetlands. Lavenham Press, Suffolk, United Kingdom, pp. 139-149.

Höller, C., Leutner, G., Lessig, U., Schreff, A., Lindenthal, W., Friedmann, L., 2005. Die Uranbelastung des bayerischen Trinkwassers. Das Gesundheitswesen 03, 45.

Howe, S.E., Davidson, C.M., McCartney, M., 1999. A preliminary investigation of the operational and isotopic speciation of uranium in sediments. Fresenius Journal of Analytical Chemistry 363, 582-584.

Hsi, C.-K., Langmuir, D., 1985. Adsorption of uranyl onto ferric oxyhydroxides: Application of the surface complexation site-binding model. Geochimica et Cosmochimica Acta 49, 1931-1941.

Idiz, E.F., Carlisle, D., Kaplan, I.R., 1986. Interaction between organic matter and trace metals in an uranium rich bog, Kern County, California, U.S.A. Applied Geochemistry 1, 573-590.

Kaplan, D.I., Serkiz, S.M., 2001. Quantification of thorium and uranium sorption to contaminated sediments. Journal of Radioanalytical and Nuclear Chemistry 248, 529-535. 
Klessa, D.A., 2000. Compartmentalisation of uranium and heavy metals into sediment and plant biomass in a constructed wetland filter. In: Rózkowski, A., Rogoz, M. (Eds.), Mine Water and the Environment, 7th International Mine Water Association Congress, Ustro, Poland, pp. 407417.

Kochenov, A.V., Zinevyev, V.V., Lovaleva, S.A., 1965. Some features of the accumulation of uranium in peat bogs. Geochemistry International 2, 65-70.

Landgraf, A., Planer-Friedrich, B., Merkel, B., 2002. Natural attenuation in a wetland under unfavorable conditions - Uranium tailing Schneckenstein/Germany. In: Merkel, B., PlanerFriedrich, B., Wolkersdorfer, C. (Eds.), Uranium in the aquatic environment. Springer, Berlin, Heidelberg, pp. 863-870.

Langmuir, D., 1978. Uranium solution-mineral equilibria at low temperatures with applications to sedimentary ore deposits. Geochimica et Cosmochimica Acta 42, 547-569.

Li, Y.H., 1982. A brief discussion on the mean oceanic residence time of elements. Geochimica et Cosmochimica Acta 46, 671-675.

Lopatkina, A.P., 1967. Conditions of accumulation of uranium in peat. Geochemistry International 4, 577-588.

Lovley, D.R., Phillips, E.J.P., Gorby, J.P., Landa, E.R., 1991. Microbial reduction of uranium. Nature 350, 413-416.

Merkel, B., 2006. Uran in Trinkwasser (Leitungswasser, Mineralwasser, Tafelwasser, Heilwasser). http://www.geo.tu-freiberg.de/ merkel/uran_index.htm.

Miller, W.P., Martens, D.C., Zelazny, L.W., Kornegay, E.T., 1986. Forms of solid phase copper in copper-enriched swine manure. Journal of Environmental Quality 15, 69-72.

Moore, G.W., 1954. Extraction of uranium from aqueous solutions by coal and some other materials. Economic Geology 49, 652-658.

Naucke, W., 1974. Chemie von Moor und Torf. In: Göttlich, K. (Ed.), Moor- und Torfkunde. Schweizerbart, Stuttgart, pp. 237-261.

Nriagu, J.O., Soon, Y.K., 1985. Distribution and isotopic composition of sulfur in lake sediments of northern Ontario. Geochimica et Cosmochimica Acta 49, 823-834.

Owen, D.E., Otton, J.K., 1995. Mountain wetlands: Efficient uranium filters - potential impacts. Ecological Engineering 5, 77-93.

Owen, D.E., Otton, J.K., Hills, F.A., Schumann, R.R., 1992. Uranium and other elements in Colorado Rocky Mountain wetlands - a reconnaissance study. U.S. Geological Survey Bulletin 1992, 33 pp.

Palmer, M.R., Edmond, J.M., 1993. Uranium in river water. Geochimica et Cosmochimica Acta 57, 4947-4955.

Pardi, R.R., 1987. U-Series disequilibrium within recent, coastal New Jersey peat. New Jersey Academy of Science Bulletin 32, 38-39.

Payne, T.E., Shinners, S., Twining, J.R., 1998. Uranium sorption on tropical wetland sediments. In: Merkel, B., Helling, C. (Eds.), Uranium mining and hydrogeology II. Proceedings of the International Conference and Workshop, Freiberg, Germany. Sven von Loga, Köln, pp. 298307.

Raskin, I., Kumar, P.B.A.N., Dushenkov, S., Salt, D.E., 1994. Bioconcentration of heavy metals by plants. Current Opinion in Biotechnology 5, 285-290.

Read, D., Lawless, T.A., Sims, R.J., Butter, K.R., 1993. The migration of uranium into peat rich soils at Broubster, Caithness, Scottland, U.K. Journal of Contaminant Hydrology 14, 277-289.

Scheffer, F., Schachtschabel, P., 2002. Lehrbuch der Bodenkunde. Spektrum Akademischer Verlag, Heidelberg, 593 pp.

Schell, W.R., Tobin, M.J., Massey, C.D., 1989. Evaluation of trace metal deposition history and potential element mobility in selected cores from peat and wetland ecosystems. The Science of the Total Environment 87/88, 19-42.

Schönbuchner, H., 2003. Untersuchungen zu Mobilität und Boden-Pflanze-Transfer von Schwermetallen auf/in uranhaltigen Haldenböden. Dissertation Friedrich-Schiller-Universität, Jena, Germany, 169 pp.

Schöner, A., 2006. Hydrogeochemische Prozesse der Uranfixierung in natürlichen Wetlands und deren Anwendbarkeit in der "passiven" Wasserbehandlung. Dissertation, Friedrich-SchillerUniversität, Jena, Germany, 373 pp. 
Schönwiese, D., 2007. Untersuchungen eines Uranvorkommens in der Oberpfalz auf Eignung als Natürliches Analogon für das Verhalten radioaktiver Elemente im Fernfeld eines hypothetischen Endlagers. Dissertation TU Braunschweig,146 pp.

Schultz, M.K., Burnett, C., Inn, K.G.W., 1998. Evaluation of a sequential extraction method for determining actinide fractionation in soils and sediments. Journal of Environmental Radioactivity 40, 155-174.

Schuster, D., 1995. Uranvererzung im Bereich von Ganggesteinen im nordöstlichen Ronneburger Erzfeld. Zeitschrift der geologischen Wissenschaften 23, 553-559.

Seidel, M., 2002. Sorption von Metallen und Halbmetallen an Sedimenten im bergbaulich beeinflussten Feuchtgebiet Lengenfeld/Vogtland. FOG - Freiberg Online Geoscience, Electronic Journal of the Freiberg Geoscience Department, Germany, 167 pp.

Seidel, M., Mannigel, S., Planer-Friedrich, B., Merkel, B., 2002. Hydrogeochemical characterisation of surface water, sorption of metal(loid)s on sediments and exchange processes within the wetland Lengenfeld/Germany. In: Merkel, B., Planer-Friedrich, B., Wolkersdorfer, C. (Eds.), Uranium in the aquatic environment. Springer, Berlin, Heidelberg, pp. 882-891.

Shinners, S., 1996. An overview of the application of constructed wetland filtration at ERA Ranger Mine, Engineering Tomorrow Today - The Darwin Summit. The National Conference of the Institution of Engineers, Darwin, NT, Australia.

Sigg, L., Stumm, W., 1995. Aquatische Chemie - Eine Einführung in die Chemie wäßriger Lösungen und natürlicher Gewässer. vdf Verlag der Fachvereine, Teubner Verlag, Zürich, Stuttgart.

Sowder, A.G., Bertsch, P.M., 2002. Speciation of uranium and nickel in aged-contaminated sediments: Coupling spatially resolved SXRF and XANES with chemical extractions. www.uga.edu/srel/SES-IIposterFinal.pdf.

Sowder, A.G., Bertsch, P.M., Morris, P.J., 2003. Partitioning and availability of uranium and nickel in contaminated riparian sediments. Journal of Environmental Quality 32, 885-889.

Swanson, V.E., Vine, J.D., 1958. Uranium in organic substances from two alpine meadows, Sierra Nevada, California. U.S. Atomic Energy Commission Report Trace Elements Investigations 740, Washington DC, pp. 209-214.

Titayeva, N.A., 1967. Association of radium and uranium with peat. Geochemistry International (translated article from Geokhimiya, No. 12, pp. 1493-1499, 1967) 4, 1168-1174.

Tixier, K., Beckie, R., 2001. Uranium depositional controls at the Prairie Flats surficial uranium deposit, Summerland, British Columbia. Environmental Geology 40, 1242-1251.

Vandenhove, H., Cuypers, A., van Hees, M., Wannijn, J., 2006. Effect of uranium and cadmium uptake on oxidative stress reactions for Phaseolus vulgaris. In: Merkel, B.J., Hasche-Berger, A. (Eds.), Uranium in the environment - mining impact and consequences. Springer, Berlin, Heidelberg, pp. 175-182.

Veselic, M., Gantar, I., Karahodzic, M., Galicic, B., 2001. Towards passive treatment of uranium mine waters. In: Prokop, G. (Ed.), 1st Image-Train Cluster-Meeting. Federal Environment Agency Ltd. Austria (Wien), Karlsruhe, Germany pp. 116-128.

WHO (2005): Uranium in drinking-water. Background document for development of WHO Guidelines for Drinking-water Quality. World Health Organization (Ed.), Report WHO/SDE/WSH/03.04/118, Geneva, Switzerland, 18 pp. www.who.int/entity/water_ sanitation_health/dwq/ chemicals/uranium290605.pdf.

Wismut GmbH, 1999. Chronik der Wismut. Wismut GmbH , Abteilung Öffentlichkeitsarbeit (Ed.), CD-ROM, Chemnitz, Germany, 2738 pp.

WRB, 2006. World reference base for soil resources 2006. Food and Agriculture Organization of the United Nations (Ed.), Report 103, Rome, Italy, 133 pp.

Zhou, P., Gu, B., 2005. Extraction of oxidized and reduced forms of uranium from contaminated soils: Effects of carbonate concentration and $\mathrm{pH}$. Environmental Science and Technology 39, 44353330 .

Zielinski, R.A., Otton, J.K., Wanty, R.B., Pierson, C.T., 1987. The geochemistry of water near a surficial organic-rich uranium deposit, northeastern Washington State, U.S.A. Chemical Geology 62, 263-289. 
Figure 1: Map showing the locations of sampled wetlands in Thuringia and Saxony, eastern part of Germany. Each sampled wetland is shown by a grey circle. Geographic coordinates of investigation area edges in format DMS:

NW edge $50^{\circ} 53^{\prime} 57,28^{\prime \prime}$ ' $12^{\circ} 04^{\prime} 36,37^{\prime}$ ' $\mathrm{E}$

NE edge $50^{\circ} 54^{\prime} 15,60^{\prime \prime}$ ' $\mathrm{N} 12^{\circ} 29^{\prime} 20,90^{\prime \prime} \mathrm{E}$

SW edge $50^{\circ} 42^{\prime} 01,46^{\prime \prime} \mathrm{N} 12^{\circ} 05^{\prime} 04,08^{\prime \prime}$ ' E

SE edge $50^{\circ} 42^{\prime} 16,41^{\prime \prime} \mathrm{N} 12^{\circ} 29^{\prime} 40,45^{\prime \prime} \mathrm{E}$

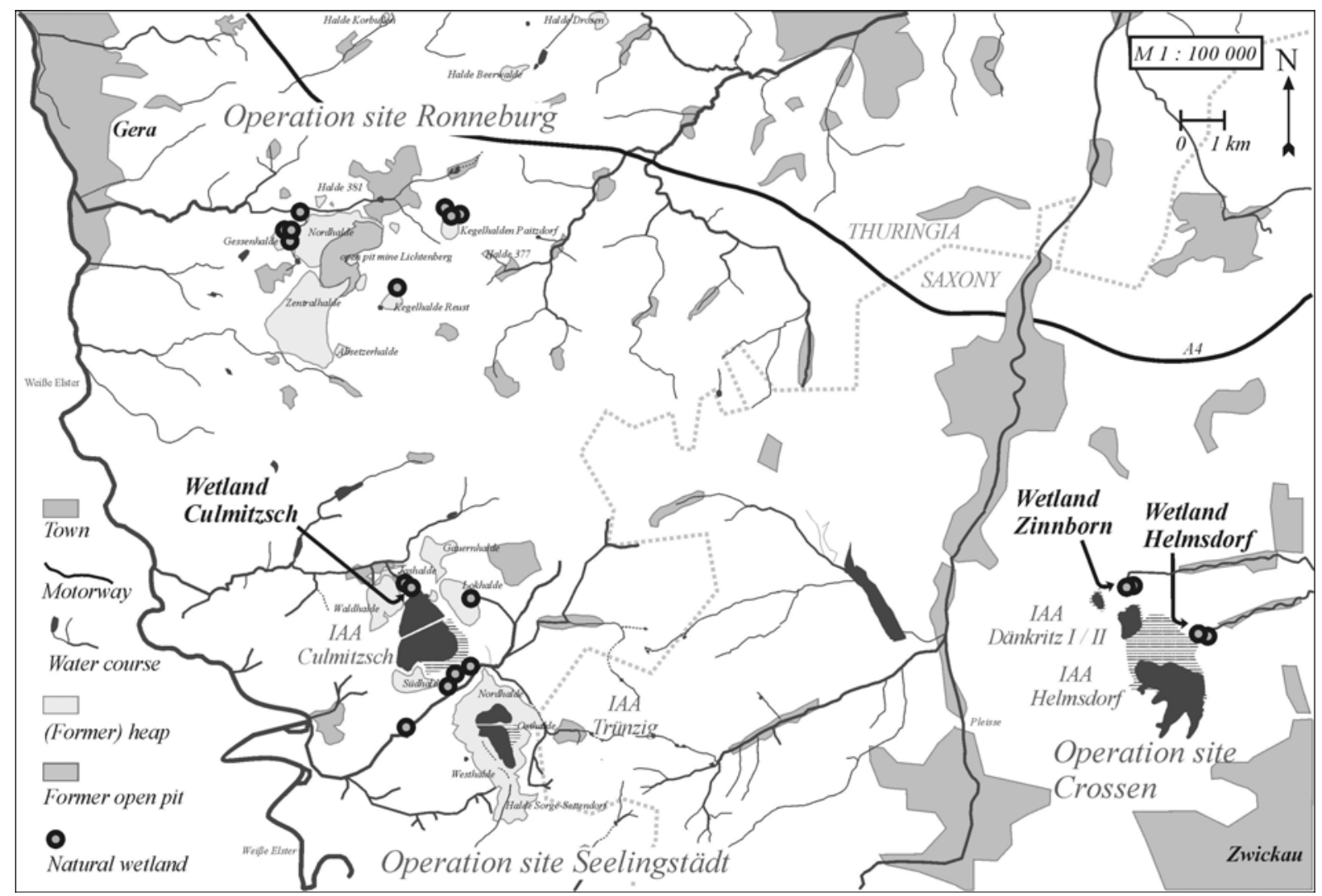


Table 1: Resuming characteristics of sampled wetlands Helmsdorf (WLHe), Culmitzsch (WLCu), and Zinnborn (WLZ) with main plant species, range of organic carbon (OC) and uranium concentrations. $(\mathrm{n}=$ number of samples.)

\begin{tabular}{|c|c|c|c|}
\hline $\begin{array}{l}\text { Characteristics of sampled wetlands } \\
\text { (RW = easting, } H W=\text { northing) }\end{array}$ & $\begin{array}{l}\text { Organic } \\
\text { carbon } \\
{[w t-\%]}\end{array}$ & $\begin{array}{l}\text { Uranium in near- } \\
\text { surface and pore } \\
\text { waters }[\mathrm{mg} / \mathrm{L}]\end{array}$ & $\begin{array}{l}\text { Uranium in substrate } \\
\text { and background } \\
\text { samples }[\mathrm{mg} / \mathrm{kg}]\end{array}$ \\
\hline \multicolumn{4}{|l|}{ WLHe } \\
\hline $\begin{array}{l}\text { - RW 4532218, HW 5625598, } 281 \mathrm{~m} \text { a.s.l. } \\
\text { - pond surface } 750 \mathrm{~m}^{2} \\
\text { - Phragmites, Carex, Typha } \\
\text { - } 41 \mathrm{~cm} \text { length of vertical profile (10 strata) } \\
\text { - distinct carbonate content } \\
\text { - } \text { soil classification (WRB*): histo-humic gleysol }\end{array}$ & $0.8-20.4$ & $\begin{array}{l}0.72-6.54(n=5) \\
0.50-2.43(n=10)\end{array}$ & $\begin{array}{l}3.50-1127(n=12) \\
360(n=1)\end{array}$ \\
\hline \multicolumn{4}{|l|}{ - WLCu } \\
\hline $\begin{array}{l}\text { - RW 4513210, HW 5627280, } 266 \mathrm{~m} \text { a.s.1. } \\
\text { - pond surface } 200 \mathrm{~m}^{2} \\
\text { - Carex } \\
\text { - } 42 \mathrm{~cm} \text { length of vertical profile ( } 5 \text { strata) } \\
\text { - no distinct carbonate content } \\
\text { - type of sediment: sapropel }\end{array}$ & $1.0-3.4$ & $\begin{array}{l}4.23-6.17(n=4) \\
0.75-4.69(n=5)\end{array}$ & $\begin{array}{l}62-443(n=6) \\
20(n=1)\end{array}$ \\
\hline \multicolumn{4}{|l|}{ - WLZ } \\
\hline $\begin{array}{l}\text { - RW 4531509, HW 5626599, } 314 \text { m a.s.l. } \\
\text { - pond surface } 20 \mathrm{~m}^{2} \text { (in a larger wetland area) } \\
\text { - Sphagnum, Carex, (Juncus, Equisetum) } \\
\text { - } 75 \mathrm{~cm} \text { length of vertical profile ( } 7 \text { strata) } \\
\text { - no distinct carbonate content } \\
\text { - } \text { soil classification (WRB*): histic gleysol / eutric } \\
\text { histosol, up to } 50 \mathrm{~cm}^{2} \text { peat mosses }\end{array}$ & $8.2-25.6$ & $\begin{array}{l}0.35-0.49(n=5) \\
0.13-1.16(n=7)\end{array}$ & $\begin{array}{l}\text { 152-8011 }(n=10) \\
62(n=1)\end{array}$ \\
\hline
\end{tabular}

*WRB $=$ World Reference Base for Soil Resources (WRB, 2006)

Table 2: Samples from stratified substrate layers of the wetlands Helmsdorf, Culmitzsch and Zinnborn, with declaration of depth and sample labelling.

\begin{tabular}{l|l|l|l|l|l}
\hline \multicolumn{3}{l|}{ Helmsdorf } & \multicolumn{2}{l|}{ Culmitzsch } & \multicolumn{2}{l}{ Zinnborn } \\
\hline depth [cm] & sample & depth [cm] & sample & depth [cm] & sample \\
\hline$-5-0$ & (fouling) & $-5-0$ & (fouling) & $-5-0$ & (fouling) \\
$0-3$ & WLHe1 & $0-8$ & WLCu1 & $0-18$ & WLZ1 \\
$3-5$ & WLHe2 & $8-14$ & WLCu2 & $18-25$ & WLZ2 \\
$5-7$ & WLHe3 & $14-22$ & WLCu3 & $25-40$ & WLZ3 \\
$8-12$ & WLHe4 & $22-31$ & WLCu4 & $40-45$ & WLZ4 \\
$12-14$ & WLHe5 & $31-42$ & WLCu5 & $45-60$ & WLZ5 \\
$14-16$ & WLHe6 & below 42 & (coarser grained & $60-68$ & WLZ6 \\
$16-18$ & WLHe7 & & minerogenic layer) & $68-75$ & WLZ7 \\
$18-23$ & WLHe8 & & & $75-83$ & (gravel) \\
$23-28$ & WLHe9 & & & & \\
$30-41$ & WLHe10 & & & & \\
below 41 & (impenetrable clay seal) & & & & \\
\hline
\end{tabular}


Table 3: Sequential extraction protocol as adapted by Sowder et al. (2003) and Batson et al. (1996), modified from Miller et al. (1986).

\begin{tabular}{l|llll}
\hline Step & Phase & Extractant & pH & Conc. [mol/L] \\
\hline 1 & water soluble & $\mathrm{H}_{2} \mathrm{O}$ pure & 5.5 & \\
2 & exchangeable & $\mathrm{Ca}\left(\mathrm{NO}_{3}\right)_{2}$ & 5 & 0.5 \\
3 & acid soluble & $\mathrm{Ca}\left(\mathrm{NO}_{3}\right)_{2} / \mathrm{CH}_{3} \mathrm{COOH}$ & 2 & $0.1 / 0.44$ \\
4 & organically bound & $\mathrm{Na}_{4} \mathrm{P}_{2} \mathrm{O}_{7}$ & 10 & 0.1 \\
5 & bound to poorly crystalline Fe oxides & $\left(\mathrm{NH}_{4}\right)_{2} \mathrm{C}_{2} \mathrm{O}_{4} / \mathrm{H}_{2} \mathrm{C}_{2} \mathrm{O}_{4}$ & 3 & $0.175 / 0.1$ \\
6 & bound to well crystalline Fe oxides & $\mathrm{C}_{6} \mathrm{H}_{5} \mathrm{Na}_{3} \mathrm{O}_{7} * 2 \mathrm{H}_{2} \mathrm{O} / \mathrm{C}_{6} \mathrm{H}_{8} \mathrm{O}_{7} / \mathrm{Na}_{2} \mathrm{~S}_{2} \mathrm{O}_{4}$ & 5 & $0.15 / 0.05 / 0.29$ \\
7 & residue & $\mathrm{HF} / \mathrm{HNO}_{3} / \mathrm{HClO}_{4}$ & $<<1$ & \\
\hline
\end{tabular}


Table 4: Elemental concentrations in water samples (surface water from profile location; pore waters from centrifugation, indicated with $*$ ) from wetlands Helmsdorf, Culmitzsch and Zinnborn (WLHe, WLCu und WLZ). Electric conductivity (cond.) and $\mathrm{pH}$ from laboratory measurement on pore waters after centrifugation; hardness = total hardness; - = insufficient volume for analyses; valid numeric round off schematised to zero (values $>$ 100) up to four places (values $<0.001$ ), excepting lower accuracy of measurement.)

\begin{tabular}{|c|c|c|c|c|c|c|c|c|c|c|c|c|c|}
\hline & $\begin{array}{r}F e \\
{[m g / L]}\end{array}$ & $\begin{array}{r}M n \\
{[m g / L]}\end{array}$ & $\begin{array}{r}U \\
{[\mathrm{mg} / \mathrm{L}]}\end{array}$ & $\begin{array}{r}A s \\
{[m g / L]}\end{array}$ & $\begin{array}{r}Z n \\
{[m g / L]}\end{array}$ & $\begin{array}{r}\mathrm{Cu} \\
{[\mathrm{mg} / \mathrm{L}]}\end{array}$ & $\begin{array}{r}N i \\
{[\mathrm{mg} / \mathrm{L}]}\end{array}$ & $\begin{array}{r}\mathrm{Co} \\
{[\mathrm{mg} / \mathrm{L}]}\end{array}$ & $\begin{array}{r}P b \\
{[m g / L]}\end{array}$ & $\begin{array}{r}\mathrm{Cr} \\
{[\mathrm{mg} / \mathrm{L}]}\end{array}$ & $\begin{array}{r}C d \\
{[m g / L]}\end{array}$ & $\begin{array}{r}\mathrm{Na} \\
{[\mathrm{mg} / \mathrm{L}]}\end{array}$ & $\begin{array}{r}M g \\
{[\mathrm{mg} / \mathrm{L}]}\end{array}$ \\
\hline$\overline{\mathrm{WLHe}_{\mathrm{aqu}}}$ & 1.07 & 1.94 & 2.03 & 0.049 & $<0.008$ & $<0.0044$ & $<0.012$ & $<0.0009$ & $<0.0082$ & 0.006 & $<0.001$ & 461 & 188 \\
\hline *WLHe1-10 $10_{\text {aqu }}$ & $\begin{array}{r}0.068- \\
0.499\end{array}$ & $\begin{array}{r}3.28- \\
13.3\end{array}$ & $\begin{array}{r}0.096- \\
2.43\end{array}$ & $\begin{array}{r}0.017- \\
0.237\end{array}$ & $<0.008$ & $<0.0044$ & $<0.012$ & $\begin{array}{r}<0.0009 \\
0.002\end{array}$ & $<0.0082$ & $\begin{array}{r}0.004- \\
0.008\end{array}$ & $<0.001$ & $\begin{array}{r}433- \\
512\end{array}$ & $\begin{array}{r}185- \\
222\end{array}$ \\
\hline $\mathrm{WLCu}_{\mathrm{aqu}}$ & 0.158 & 1.72 & 6.17 & $<0.0001$ & 0.050 & 0.003 & 0.008 & 0.0014 & 0.011 & $<0.0002$ & $<0.0001$ & 1325 & 224 \\
\hline$* \mathrm{WLCu} 1-5_{\mathrm{aqu}}$ & $\begin{array}{r}0.098- \\
2.310\end{array}$ & $\begin{array}{r}4.25- \\
5.60\end{array}$ & $\begin{array}{r}0.748- \\
4.69\end{array}$ & $\begin{array}{r}0.061- \\
0.274\end{array}$ & $<0.047$ & $<0.002$ & $\begin{array}{r}0.015- \\
0.043\end{array}$ & $<0.001$ & $\begin{array}{r}0.002- \\
0.003\end{array}$ & $<0.005$ & $<0.0001$ & $\begin{array}{r}521- \\
630\end{array}$ & $\begin{array}{r}139- \\
183\end{array}$ \\
\hline $\mathrm{WLZ}_{\mathrm{aqu}}$ & 0.057 & 0.245 & 0.426 & 0.003 & 0.025 & 0.004 & 0.006 & 0.0017 & 0.003 & 0.003 & 0.000 & 160 & 33.1 \\
\hline${ }^{*} \mathrm{WLZ1} 1-7_{\mathrm{aqu}}$ & $\begin{array}{r}0.052- \\
0.188\end{array}$ & $\begin{array}{r}0.142- \\
0.267\end{array}$ & $\begin{array}{r}0.133- \\
1.16\end{array}$ & $\begin{array}{r}0.001- \\
0.006\end{array}$ & $\begin{array}{r}<0.0025- \\
0.089\end{array}$ & $\begin{array}{r}0.002- \\
0.003\end{array}$ & $\begin{array}{r}0.008- \\
0.010\end{array}$ & 0.001 & $\begin{array}{r}0.002- \\
0.004\end{array}$ & $\begin{array}{r}0.002- \\
0.005\end{array}$ & $\begin{array}{r}<0.0001- \\
0.001\end{array}$ & $\begin{array}{r}156- \\
240\end{array}$ & $\begin{array}{r}28.5- \\
45.5\end{array}$ \\
\hline
\end{tabular}

\begin{tabular}{|c|c|c|c|c|c|c|c|c|c|c|c|c|c|c|c|c|c|}
\hline & $\begin{array}{r}A I \\
{[\mathrm{mg} / \mathrm{L}]}\end{array}$ & $\begin{array}{r}K \\
{[\mathrm{mg} / \mathrm{L}]}\end{array}$ & $\begin{array}{r}\mathrm{Ca} \\
{[\mathrm{mg} / \mathrm{L}]}\end{array}$ & $\begin{array}{r}\mathrm{Sr} \\
{[\mathrm{mg} / \mathrm{L}]}\end{array}$ & $\begin{array}{r}B a \\
{[m g / L]}\end{array}$ & $\begin{array}{r}S i \\
{[m g / L]}\end{array}$ & $\begin{array}{r}\mathrm{Cl} \\
{[\mathrm{mg} / \mathrm{L}]}\end{array}$ & $\begin{array}{r}F \\
{[m g / L]}\end{array}$ & $\begin{array}{r}\mathrm{SO}_{4} \\
{[\mathrm{mg} / \mathrm{L}]}\end{array}$ & $\begin{array}{r}\mathrm{NO}_{3} \\
{[\mathrm{mg} / \mathrm{L}]}\end{array}$ & $\begin{array}{r}\mathrm{NO}_{2} \\
{[\mathrm{mg} / \mathrm{L}]}\end{array}$ & $\begin{array}{r}\mathrm{PO}_{4} \\
{[\mathrm{mg} / \mathrm{L}]}\end{array}$ & $\begin{array}{r}\mathrm{HCO}_{3} \\
{[\mathrm{mg} / \mathrm{L}]}\end{array}$ & $\begin{array}{l}\text { hardness } \\
\text { [mmol/L] }\end{array}$ & $\begin{array}{r}\mathrm{DOC} \\
{[\mathrm{mg} / \mathrm{L}]} \\
\end{array}$ & $\begin{array}{r}\text { cond. } \\
\text { [mS/cm] }\end{array}$ & $p H$ \\
\hline $\mathrm{WLHe}_{\mathrm{aqu}}$ & $<0.0048$ & 6.91 & 422 & 0.303 & 0.024 & 7.3 & 365 & $<1$ & 1730 & $<1.5$ & 0.042 & 0.09 & 572.25 & 18.3 & 13 & 4.03 & 7.04 \\
\hline$*$ WLHe1-10 & $<0.0048$ & $\begin{array}{r}12.3- \\
90.0\end{array}$ & $\begin{array}{r}404- \\
441\end{array}$ & $\begin{array}{r}0.308- \\
0.471\end{array}$ & $\begin{array}{r}0.019- \\
0.208\end{array}$ & $\begin{array}{r}<5- \\
12\end{array}$ & $\begin{array}{r}395- \\
523\end{array}$ & $<1$ & $\begin{array}{r}1465- \\
2000\end{array}$ & $<1.5$ & $<1.5$ & $\begin{array}{r}<0.05- \\
9.7\end{array}$ & - & $\begin{array}{r}17.7- \\
20.0\end{array}$ & $\begin{array}{r}18- \\
78\end{array}$ & $\begin{array}{r}1.49- \\
4.38\end{array}$ & $\begin{array}{r}7.29- \\
7.96\end{array}$ \\
\hline $\mathrm{WLCu}_{\mathrm{aqu}}$ & 0.020 & 20.6 & 245 & 0.835 & 0.054 & 2.6 & 289 & 0.94 & 3192 & 5 & 0.351 & $<0.05$ & 831.95 & 15.3 & 6.9 & 7.38 & 7.42 \\
\hline *WLCu1-5aqu & $<0.042$ & $\begin{array}{r}8.72- \\
18.6\end{array}$ & $\begin{array}{r}229- \\
268\end{array}$ & $\begin{array}{r}0.349- \\
0.437\end{array}$ & $\begin{array}{r}0.078- \\
0.094\end{array}$ & $\begin{array}{l}8.5- \\
16.5\end{array}$ & $\begin{array}{r}124- \\
162\end{array}$ & $\begin{array}{r}0.56- \\
0.96\end{array}$ & $\begin{array}{r}1384- \\
1576\end{array}$ & - & - & $\begin{array}{r}<0.05- \\
0.87\end{array}$ & - & $\begin{array}{r}12.2- \\
14.0\end{array}$ & $\begin{array}{r}16- \\
21\end{array}$ & $\begin{array}{r}3.29- \\
4.10\end{array}$ & $\begin{array}{r}7.78- \\
8.19\end{array}$ \\
\hline $\mathrm{WLZ}_{\mathrm{aqu}}$ & 0.079 & 20.5 & 58.1 & 0.323 & 0.050 & 1.7 & 143 & 0.5 & 332 & 60 & $<0.01$ & $<0.05$ & 190.5 & 2.90 & 22 & 1.44 & 6.58 \\
\hline *WLZ1-7 & $\begin{array}{r}0.045- \\
0.311\end{array}$ & $\begin{array}{r}20.8- \\
133\end{array}$ & $\begin{array}{r}53.6- \\
70.1\end{array}$ & $\begin{array}{r}0.328- \\
0.405\end{array}$ & $\begin{array}{r}0.056- \\
0.198\end{array}$ & $\begin{array}{r}<1.5- \\
2.7\end{array}$ & $\begin{array}{r}132- \\
313\end{array}$ & $\begin{array}{r}0.3- \\
0.7\end{array}$ & $\begin{array}{r}318- \\
426\end{array}$ & $\begin{array}{l}8- \\
67\end{array}$ & - & $<0.05$ & - & $\begin{array}{r}2.51- \\
3.57\end{array}$ & $\begin{array}{r}12- \\
26\end{array}$ & $\begin{array}{r}1.03- \\
2.08\end{array}$ & $\begin{array}{r}6.63- \\
6.90\end{array}$ \\
\hline
\end{tabular}


Table 5: Spearman correlation coefficients $\mathbf{r}_{\mathbf{s}}$ for uranium in relation to selected anions/ligands from pore water analyses in Helmsdorf (WLHe, $\mathrm{n}=10$ ), Culmitzsch (WLCu, n=5) and Zinnborn (WLZ, n=7). (DIC and DOC from eluates; normalised data to $\mathrm{Si}$; - = measured values below detection limit.)

\begin{tabular}{|c|c|c|c|c|c|c|}
\hline U correlation to & $\begin{array}{r}\text { WLHe: } \\
r_{s}\end{array}$ & $\begin{array}{r}\text { WLCu: } \\
r_{s}\end{array}$ & $\begin{array}{r}W L Z: \\
r_{s} \\
\end{array}$ & $\begin{array}{c}\text { WLHe: } \\
r_{\text {s. normalised }}\end{array}$ & $\begin{array}{r}\text { WLCu: } \\
r_{\text {s. normalised }}\end{array}$ & $\begin{array}{r}\text { WLZ: } \\
r_{\text {s. normalised }}\end{array}$ \\
\hline $\mathrm{Cl}$ & 0.13 & 0.90 & -0.07 & 0.43 & -0.60 & 0.54 \\
\hline $\mathrm{F}$ & - & 1.00 & 0.02 & - & -0.30 & 0.82 \\
\hline $\mathrm{SO}_{4}$ & 0.03 & 0.90 & 0.11 & 0.36 & -0.80 & 0.61 \\
\hline $\mathrm{PO}_{4}$ & -0.09 & 0.60 & - & -0.36 & 0.60 & - \\
\hline DIC & 0.67 & -0.70 & 0.23 & 0.35 & -0.89 & 0.51 \\
\hline DOC & 0.70 & 0.70 & 0.23 & 0.20 & -0.22 & 0.77 \\
\hline
\end{tabular}


Table 6: Elemental concentrations in sediment samples from substrate strata of wetlands Helmsdorf (WLHe), Culmitzsch (WLCu) and Zinnborn (WLZ). (Digestion with HF among other chemicals, ICP-OES and ICP-MS measurement; concentrations in [mg/kg], referred to dry mass DM; RSD = relative standard deviation in [wt-\%]; valid numeric round off schematised to two places $\geq 0$ at least, RSD to $\leq$ one place. As a rule one sample per strata was digested, with some exceptions presenting mean values of two and three samples respectively from one strata.)

\begin{tabular}{|c|c|c|c|c|c|c|c|c|c|c|c|c|}
\hline & $\begin{array}{r}F e \\
{[\mathrm{mg} / \mathrm{kg}]}\end{array}$ & $\begin{array}{r}M n \\
{[\mathrm{mg} / \mathrm{kg}]}\end{array}$ & $\begin{array}{r}U \\
{[\mathrm{mg} / \mathrm{kg}]}\end{array}$ & $\begin{array}{r}A s \\
{[\mathrm{mg} / \mathrm{kg}]}\end{array}$ & $\begin{array}{r}\mathrm{Zn} \\
{[\mathrm{mg} / \mathrm{kg}]} \\
\end{array}$ & $\begin{array}{r}\mathrm{Cu} \\
{[\mathrm{mg} / \mathrm{kg}]} \\
\end{array}$ & $\begin{array}{r}\mathrm{Ni} \\
{[\mathrm{mg} / \mathrm{kg}]}\end{array}$ & $\begin{array}{r}\mathrm{Co} \\
{[\mathrm{mg} / \mathrm{kg}]}\end{array}$ & $\begin{array}{r}P b \\
{[\mathrm{mg} / \mathrm{kg}]}\end{array}$ & $\begin{array}{r}\mathrm{Cr} \\
{[\mathrm{mg} / \mathrm{kg}]}\end{array}$ & $\begin{array}{r}\mathrm{Cd} \\
{[\mathrm{mg} / \mathrm{kg}]}\end{array}$ & $\begin{array}{r}L i \\
{[\mathrm{mg} / \mathrm{kg}]}\end{array}$ \\
\hline WLCu1-5 & $30527-45054$ & 669-1199 & $62-443$ & $49-118$ & $207-773$ & $49-74$ & $41-119$ & $13-21$ & $61-237$ & $44-79$ & $1.1-5.1$ & $87-155$ \\
\hline WLZ1-7 & $2520-7919$ & $39-2439$ & $152-7562$ & $7.6-45$ & $28-159$ & $11-37$ & $18-49$ & $4.2-75$ & $27-176$ & $33-70$ & $0.75-11$ & $3.1-35$ \\
\hline
\end{tabular}

\begin{tabular}{|c|c|c|c|c|c|c|c|c|c|c|c|}
\hline & $\begin{array}{r}\mathrm{Na} \\
{[\mathrm{mg} / \mathrm{kg}]}\end{array}$ & $\begin{array}{r}M g \\
{[\mathrm{mg} / \mathrm{kg}]}\end{array}$ & $\begin{array}{r}A l \\
{[\mathrm{mg} / \mathrm{kg}]}\end{array}$ & $\begin{array}{r}P \\
{[\mathrm{mg} / \mathrm{kg}]}\end{array}$ & $\begin{array}{r}K \\
{[\mathrm{mg} / \mathrm{kg}]}\end{array}$ & $\begin{array}{r}\mathrm{Ca} \\
{[\mathrm{mg} / \mathrm{kg}]}\end{array}$ & $\begin{array}{r}\mathrm{Sr} \\
{[\mathrm{mg} / \mathrm{kg}]} \\
\end{array}$ & $\begin{array}{r}B a \\
{[\mathrm{mg} / \mathrm{kg}]}\end{array}$ & $\begin{array}{r}V \\
{[\mathrm{mg} / \mathrm{kg}]}\end{array}$ & $\begin{array}{r}\mathrm{Zr} \\
{[\mathrm{mg} / \mathrm{kg}]} \\
\end{array}$ & $\begin{array}{r}T i \\
{[\mathrm{mg} / \mathrm{kg}]} \\
\end{array}$ \\
\hline WLCu1-5 & $3960-5614$ & $10158-19275$ & $58927-94641$ & $467-716$ & $28682-43207$ & $10413-24525$ & $92-137$ & 509-1049 & $74-171$ & $180-236$ & $4810-6574$ \\
\hline WLZ1-7 & $1297-3158$ & $1276-2831$ & 28558-108942 & 246-939 & $667-7206$ & $2890-10303$ & $43-93$ & $82-215$ & $7.8-43$ & $17-188$ & $319-4158$ \\
\hline
\end{tabular}


Table 7: CNS elemental analyses (Heraeus Vario EL) from wetland substrates Helmsdorf, Culmitzsch und Zinnborn (WLHe, WLCu and WLZ). $U$ [mg/kg DM] is provided for comparison. In Zinnborn, values for TIC and OC were calculated, based on Scheibler method. (Values in weight percent; $\mathrm{C} / \mathrm{N}$ and $\mathrm{C} / \mathrm{S}$ ratios from atomic weight proportions with $\mathrm{OC}, \mathrm{TN}$ and $\mathrm{TS}$ values; $\mathrm{T}=$ total.)

\begin{tabular}{|c|c|c|c|c|c|c|c|c|c|c|}
\hline Sample & $\begin{array}{r}U \\
{[\mathrm{mg} / \mathrm{kg}]}\end{array}$ & $\begin{array}{r}T C \\
{[\%]}\end{array}$ & $\begin{array}{l}\text { TIC } \\
{[\%]} \\
\end{array}$ & $\begin{array}{r}O C \\
{[\%]}\end{array}$ & $\begin{array}{r}T N \\
{[\%]} \\
\end{array}$ & $\begin{array}{r}\text { TS } \\
{[\%]} \\
\end{array}$ & $C / N$ & $C / S$ & $\begin{array}{r}{ }^{*} \text { organic } \\
\text { matter [\%] }\end{array}$ & $\begin{array}{l}\text { **inorganic } \\
\text { carbon }[\%]\end{array}$ \\
\hline WLHe1 & 130 & 17.25 & 8.95 & 8.30 & 0.73 & 0.84 & 13 & 26 & 17 & 75 \\
\hline WLHe2 & 236 & 18.29 & 7.75 & 10.54 & 0.92 & 1.07 & 13 & 26 & 21 & 65 \\
\hline WLHe3 & 1117 & 18.83 & 7.15 & 11.68 & 1.06 & 1.20 & 13 & 26 & 23 & 60 \\
\hline WLHe4 & 1105 & 17.47 & 3.23 & 14.24 & 1.06 & 2.33 & 16 & 16 & 28 & 27 \\
\hline WLHe5 & 747 & 18.32 & 2.98 & 15.34 & 1.22 & 2.63 & 15 & 16 & 31 & 25 \\
\hline WLHe6 & 172 & 20.77 & 2.00 & 18.77 & 1.52 & 2.36 & 14 & 21 & 38 & 17 \\
\hline WLHe7 & 111 & 21.56 & 2.21 & 19.35 & 1.55 & 2.44 & 15 & 21 & 39 & 18 \\
\hline WLHe8 & 4.8 & 22.32 & 1.96 & 20.36 & 1.30 & 3.03 & 18 & 18 & 41 & 16 \\
\hline WLHe9 & 268 & 8.19 & 1.03 & 7.15 & 0.39 & 1.05 & 21 & 18 & 14 & 8.6 \\
\hline WLHe10 & 3.5 & 1.04 & 0.20 & 0.83 & 0.07 & 0.23 & 14 & 10 & 1.7 & 1.7 \\
\hline WLCu1 & 240 & 4.53 & 1.47 & 3.06 & 0.33 & 1.17 & 11 & $7 * * *$ & 6.1 & 12 \\
\hline WLCu2 & 443 & 2.09 & 0.67 & 1.41 & 0.13 & 0.78 & 13 & $5 * * *$ & 2.8 & 5.6 \\
\hline WLCu3 & 95 & 1.69 & 0.55 & 1.14 & 0.08 & 0.88 & 17 & $3 * * *$ & 2.3 & 4.6 \\
\hline WLCu4 & 62 & 1.55 & 0.54 & 1.01 & 0.08 & 0.46 & 15 & $6 * * *$ & 2.0 & 4.5 \\
\hline WLCu5 & 70 & 4.63 & 1.22 & 3.41 & 0.28 & 0.95 & 14 & $10 * * *$ & 6.8 & 10 \\
\hline WLZ1 & 2234 & 27.81 & 2.25 & 25.56 & 0.87 & 0.59 & 34 & 116 & 51 & 19 \\
\hline WLZ2 & 7562 & 26.04 & 0.51 & 25.53 & 1.04 & 0.94 & 29 & 73 & 51 & 4.2 \\
\hline WLZ3 & 1163 & 19.90 & 0.28 & 19.62 & 0.92 & 0.56 & 25 & 94 & 39 & 2.3 \\
\hline WLZ4 & 2965 & 21.19 & 0.13 & 21.06 & 0.97 & 0.63 & 25 & 89 & 42 & 1.1 \\
\hline WLZ5 & 152 & 10.73 & 0.31 & 10.42 & 0.41 & 0.37 & 30 & 75 & 21 & 2.5 \\
\hline WLZ6 & 391 & 11.63 & 0.50 & 11.13 & 0.43 & 0.31 & 30 & 96 & 22 & 4.2 \\
\hline WLZ7 & 258 & 8.63 & 0.47 & 8.16 & 0.36 & 0.23 & 26 & 95 & 16 & 3.9 \\
\hline
\end{tabular}

*Provided that $\mathrm{OC}$ is stabilised completely in humic substances.

** Provided that TIC is mineralised completely as calcite minerals.

*** The inorganic $\mathrm{S}$ fraction in Culmitzsch is in the range of $60-85 \mathrm{wt}-\%$ of TS; therefore, $\mathrm{C} / \mathrm{S}$ is not indicative with respect to soil formation processes. 
Helmsdorf
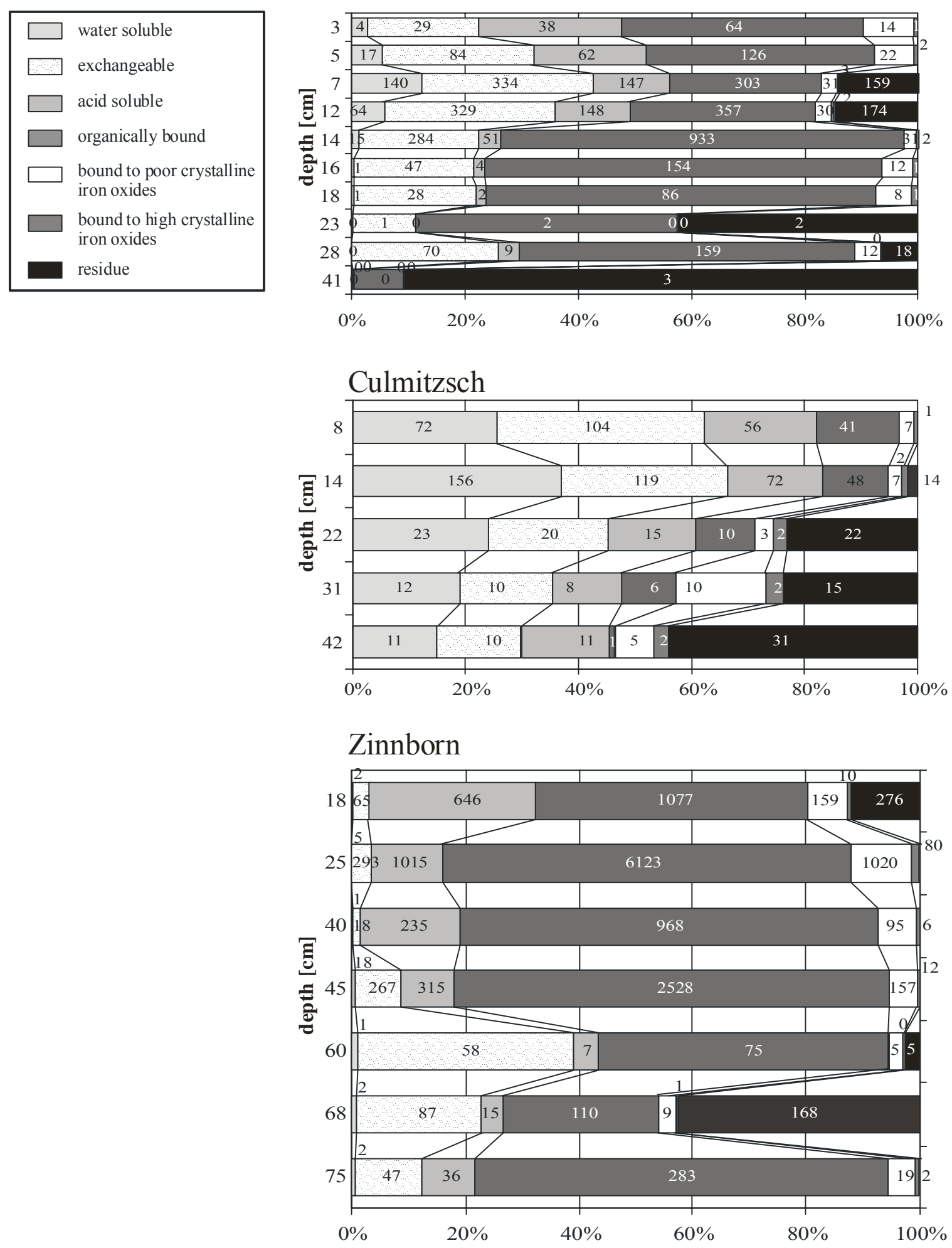

Figure 2: Sequential extraction of substrates from wetlands Helmsdorf, Culmitzsch and Zinnborn. The diagrams sum up the percent of uranium in the different extraction phases, presenting the uranium distribution of the wetland substrate strata in vertical profiles. The concentrations of the residue (step 7) are calculated from digestions of aliquots. Data in the bars give the absolute uranium concentrations in $\mathrm{mg} / \mathrm{kg} \mathrm{DM}$. The thickness of the bars indicates schematically the thickness of the sampled strata. Vertical axis not to scale. 
Table 8: Sequential extraction of soils and sediment with different procedures: Phases where uranium was distributed predominantly. (Literature data.)

\begin{tabular}{l|ll}
\hline Fraction & Reference & Extracted material \\
\hline exchangeable & (Seidel et al., 2002) & wetland sediments \\
organically bound and exchangeable & (Kaplan and Serkiz, 2001; & wetland sediments \\
& $\begin{array}{l}\text { Sowder et al., 2003) } \\
\text { (Read et al., 1993; }\end{array}$ & $\begin{array}{l}\text { wetland sediments } \\
\text { wetland sediments }\end{array}$ \\
organic phase & Braithwaite et al., 1997) & \\
organic-sulphidic phase & (Howe et al., 1999; Beckers, & sediments; floodplain \\
& 2005) & sediments \\
organic-sulphidic phase or crystalline Fe oxides & (Czegka et al., 1998) & river sediments \\
Fe and Mn oxides & (Coetzee et al., 2002) & wetland sediments \\
residue and carbonates & (Schultz et al., 1998) & marine sediments \\
residue and bound to poor crystalline Fe oxides & (Schönbuchner, 2003) & spoil heap material \\
residue & (Dhoum and Evans, 1998) & contaminated soils \\
\hline
\end{tabular}

